Vol. 23, No. 2, pp. 211 230, 2020.

\title{
A review of smart exsolution catalysts for the application of gas phase reactions
}

\section{Rui Huang, Hyung Jun Kim, Jeong Woo Han ${ }^{\dagger}$}

Department of Chemical Engineering, Pohang University of Science and Technology (POSTECH), Pohang, Gyeongbuk 37673, Republic of Korea

\section{기상 반응용 스마트 용출 촉매 연구 동향}

\author{
황루이, 김형준, 한정우 ${ }^{\dagger}$ \\ 포항공과대학교 화학공학과
}

(Received May 18, 2020; Accepted June 2, 2020)

\begin{abstract}
Perovskite-type oxides with the nominal composition of $\mathrm{ABO}_{3}$ can exsolve the $\mathrm{B}$-site transition metal upon the controlled reduction. In this exsolution process, the transition metal emerges from the oxide lattice and migrates to the surface at which it forms catalytically active nanoparticles. The exsolved nanoparticles can recover back to the bulk lattice under oxidation treatment. This unique regeneration character by the redox treatment provides uniformly dispersed noble metal nanoparticles. Therefore, the conventional problem of traditional impregnated metal/support, i.e., sintering during reaction, can be effectively avoided by using the exsolution phenomenon. In this regard, the catalysts using the exsolution strategy have been well studied for a wide range of applications in energy conversion and storage devices such as solid oxide fuel cells and electrolysis cells (SOFCS and SOECS) because of its high thermal and chemical stability. On the other hand, although this exsolution strategy can also be applied to gas phase reaction catalysts, it has seldomly been reviewed. Here, we thus review recent applications of the exsolution catalysts to the gas phase reactions from the aspects of experimental measurements, where various functions of the exsolved particles were utilized. We also review non-perovskite type metal oxides that might have exolution phenomenon to provide more possibilities to develop higher efficient catalysts.
\end{abstract}

Keywords: exsolution catalysts, gas phase reaction, smart catalyst, perovskite

'Corresponding Author: Jeong Woo Han

E-mail: jwhan@postech.ac.kr 


\section{특 집}

\section{1. 서론}

용출(exsolution) 현상은 외부 처리 조건(가열 또는 환원)에 의해 소재 내부에 있던 금속이 표면으로 석출되 는 현상을 말한다. ${ }^{1)}$ 용출 현상이 제일 많이 활용되는 재 료는 $\mathrm{ABX}_{3}$ 와 같은 결정 구조를 갖는 물질인 페로브스 카이트(perovskite)이다. 일반적으로, 페로브스카이트 형 산화물은 $\mathrm{ABO}_{3}$ 결정 구조를 갖는다. 12 개 산소 원자 와 배위하며 이온 반경이 큰 양이온은 $\mathrm{A}$-사이트를 차지 하고, 6 개의 배위를 갖는 상대적으로 이온 반경이 작은 양이온은 $\mathrm{B}$-사이트를 차지한다. ${ }^{2)}$ 열환원 처리 시, $\mathrm{B}-$ 사이트에 있던 전이 금속이 산화물 격자에서 표면으로 이동하여 나노 입자를 형성하는 과정을 페로브스카이트 에서의 용출이라고 한다. 용출된 금속 나노 입자는 산화 처리 하에서 벌크 격자로 다시 들어가 원복 될 수 있으 며, 이는 처리 조건에 따라 가역적으로 금속 원자를 이 동시킬 수 있다.

종래의 방법으로 합성된 금속/지지체의 안정성 문 제는 용출 현상을 활용하여 해결 될 수 있다. 2002년 Nishihata 연구진 ${ }^{3)}$ 은 처음으로 이 현상을 이용하여 자 동차 배기가스 저감을 위한 촉매 컨버터에 사용하였다. $\mathrm{LaFeO}_{3}$ 페로브스카이트 산화물에 코발트 $(\mathrm{Co})$ 및 팔라 듐 $(\mathrm{Pd})$ 도핑(doping) 후, 환원 및 산화 분위기에 의해 $\mathrm{Pd}$ 원소는 가역적으로 모체 격자에서 표면으로 이동되 었다. 단일상 격자에서 용출된 $\mathrm{Pd}$ 금속은 표면에서 균
일한 분포로 관찰되었다. 이러한 표면에 고르게 분산된 $\mathrm{Pd}$ 금속에 의해서 일산화탄소 $(\mathrm{CO})$, 탄화수소 및 질소 산화물 등의 자동차 배기가스 중 유해 물질들을 저온에 서 효율적으로 이산화탄소 $\left(\mathrm{CO}_{2}\right)$, 물 $\left(\mathrm{H}_{2} \mathrm{O}\right)$ 및 질소 $\left(\mathrm{N}_{2}\right)$ 등으로 전환시켜 저감시킬 수 있었다. 뿐만 아니라, 산 화 환원 분위기에 변화를 주며 촉매의 노화(aging) 테스 트 시, $\mathrm{Pd}$ 가 용출된 촉매는 100 시간 동안 높은 활성을 유지하였다. 반면에, 일반적으로 합성된 $\mathrm{Pd} / \mathrm{Al}_{2} \mathrm{O}_{3}$ 촉매 의 활성은 $10 \%$ 가 감소되었다(Fig. 1a). ${ }^{3)}$ 기상 반응에 성 공적으로 적용된 용출 현상은 종래의 합성에서 효과적 으로 제어하기 어려윘던 금속-지지체 상호 작용을 강화 시킴에 따라 표면에 노출된 금속의 응집을 억제할 수 있 었다. 특히, 환원 처리를 통해 용출된 금속은 지지 촉매 표면에 소켓처럼 나노 금속 입자가 위치함에 따라 고온 에서의 금속의 이동성을 효과적으로 억제할 수 있었다.

이러한 열과 화학적 안정성을 갖는 페로브스카이트 산화물은 에너지의 저장 및 전환 장치의 반응 촉매로 도 활용될 수 있다. 특히, 고체산화물 연료전지 (Solid Oxide Fuel Cells, SOFCs) 및 고체산화물 수전해전지 (Solid Oxide Electrolysis Cells, SOECs)에서의 전기 화학 반응 촉매로 활발히 적용되어왔다. 보다 더 효율적 인 소재 개발을 위해 다양한 실험으로 진행된 연구뿐만 아니라 계산화학적 방법이 활용되어 $\mathrm{SOC}$ 재료의 합리 적인 설계를 촉진해왔고, ${ }^{5-7,9-11)}$ 더불어 용출 현상의 형 성 메커니즘 및 원소에 따른 용출 추세에 대한 연구 결

\section{a}

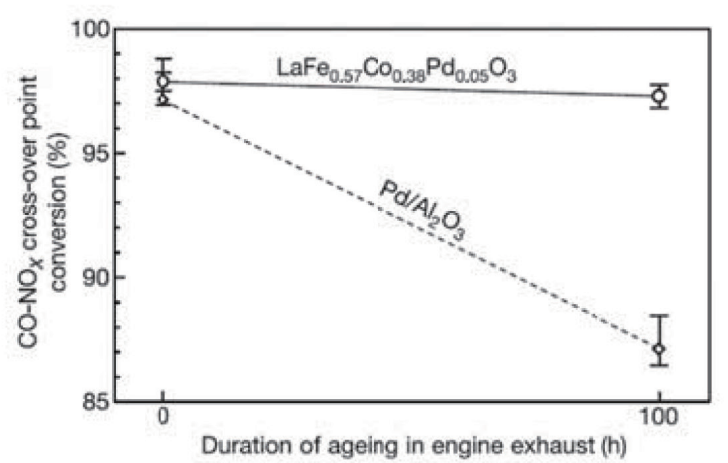

b

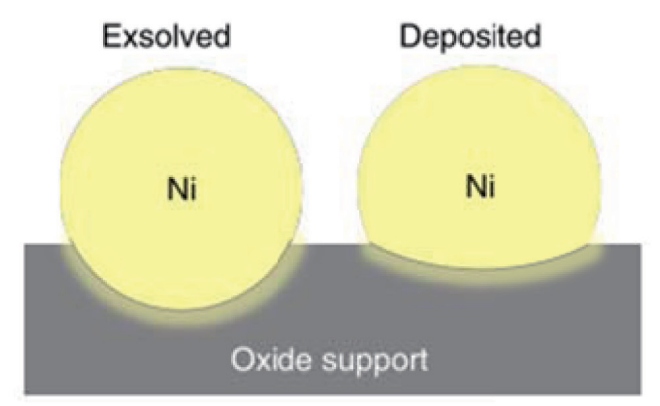

Fig. 1. a 촉매가 aging하는 동안 활성의 변화. ${ }^{3)} \mathrm{b}$ 용출 및 증착된 $\mathrm{Ni}$ 의 입자/산화물 지지체 계면의 개략도. ${ }^{13)}$ 
a

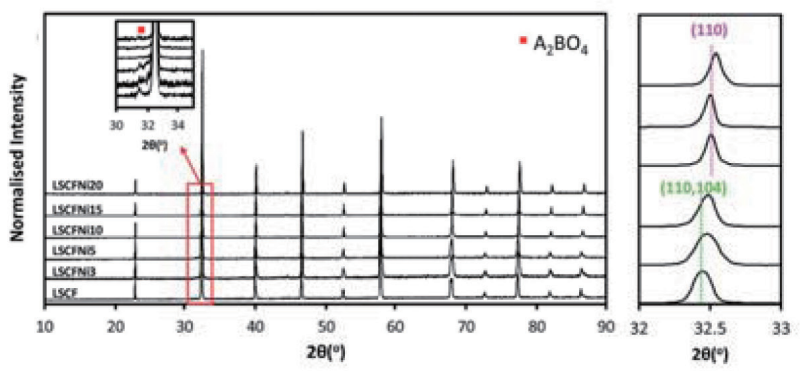

b

\section{C}

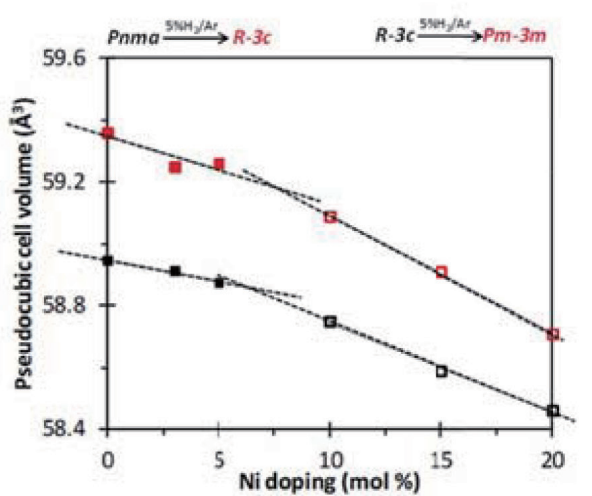

Fig. 2. a LSCFNi 환원 후 XRD 결과; b 2a에서 32-33 구간의 확대; c LSCFNi의 Ni 도핑과 단위 셀 부피(검은색: 합성한 샘플; 빨간색: 환원된 샘플)의 관계.19)

과들이 제시되어 왔다. ${ }^{10-11)}$ 용출 현상의 본질 및 이의 $\mathrm{SOFC}$ 로의 응용과 관련한 리뷰 논문들도 많이 출간되어 왔다. ${ }^{12)}$

이에 반해, 용출 현상을 활용한 고성능 촉매 설계는 $\mathrm{CO}$ 산화, 수소에 의한 $\mathrm{CO}_{2}$ 환원, 메탄 $\left(\mathrm{CH}_{4}\right)$ 및 $\mathrm{CO}_{2}$ 로 부터 합성 가스의 생산과 관련되는 메탄의 건식 개질 반 응(Dry Reforming of Methane, DRM), 역수성가스 전 환반응(reverse Water Gas Shift reaction, rWGS) 등 을 포함한 다양한 기상 반응에서 성공적으로 적용되어 왔지만, 이와 관련하여 총괄적으로 정리한 리뷰 논문은 극히 드문 것이 현실이다. 따라서 더 효율적이고 저렴한 촉매의 개발을 위하여 이러한 기상 반응용 스마트 용출 촉매의 연구 동향을 살펴볼 필요가 있다.

전통적으로 기체 상 반응에 적용되는 촉매들은 금속 을 지지체에 함침 또는 침전하여 제작하는데, 이렇게 제 조된 촉매는 고온 반응 조건하에서 쉽게 금속이 응집되 어 반응 활성사이트를 잃게 된다. 반면에, 금속이 용출 된 촉매는 초기에 산화물 지지 촉매의 격자에 원자 단 위로 고르게 분포되어 있는 도핑된 원자들이 그 표면으 로 이동하여 나노 입자를 형성하기 때문에, 지지 촉매와 강한 결합을 갖을 뿐만 아니라 표면에 균일한 입자를 얻 을 수 있다(Fig. 1b). ${ }^{13)}$ 따라서, 반응 과정 중에 발생하 는 촉매 불활성화 문제를 해결할 수 있다. 더 나아가, 산 화 또는 환원 처리에 의해 금속들이 가역적으로 이동될
수 있는 장점 때문에 불활성화를 유도하는 부산물이 표 면에 형성되어도 재생이 가능하다. 최근에, 용출 현상 은 단순히 페로브스카이트 산화물에서만 국한되지 않 고, 더 넓은 반응에 응용 가능한 기타 산화물으로도 범 위를 확장된 연구들이 보고되고 있다. 예를 들어 spinel, fluorite 및 rutile-type인 산화물에도 용출 현상이 관 찰되었다. ${ }^{14-18)}$ 본 연구진은 용출 현상을 이용하여 성공 적으로 기상 반응에 적용한 연구 동향에 대해서 소개하 고자 한다.

\section{2. 용출 현상에 대한 실험적 관찰}

이 파트에서는 용출 현상을 확인하는데 있어서 실험 적으로 유용한 방법들을 제시하고자 한다. 기본적으로 $\mathrm{XRD}$ 분석은 용출 현상을 확인할 수 있는 방법으로 종종 사용된다. 페로브스카이트의 구조에 기반한 공간 그룹 (space group) 및 격자의 변화를 용이하게 관찰할 수 있 으며, 표면에 용출된 입자의 유무를 효율적으로 확인할 수 있다.

예를 들어, Fig. $2 \mathrm{a}$ 는 $\left(\mathrm{La}_{0.75} \mathrm{Sr}_{0.25}\right)\left(\mathrm{Cr}_{0.5} \mathrm{Fe}_{0.5}\right) \mathrm{O}_{3}$ 에 $\mathrm{Ni}$ 농도가 다양하게 혼입된 초기 물질에 환원 처리를 가한 샘플들의 XRD 결과이다. 기본적으로 페로브스카이트 구조는 붕괴되지 않았으며, $\mathrm{Ni}$ 의 도핑 농도 증가에 따 라 이차 상인 $\mathrm{A}_{2} \mathrm{BO}_{4}$ (Reddlesden-Popper phase)가 


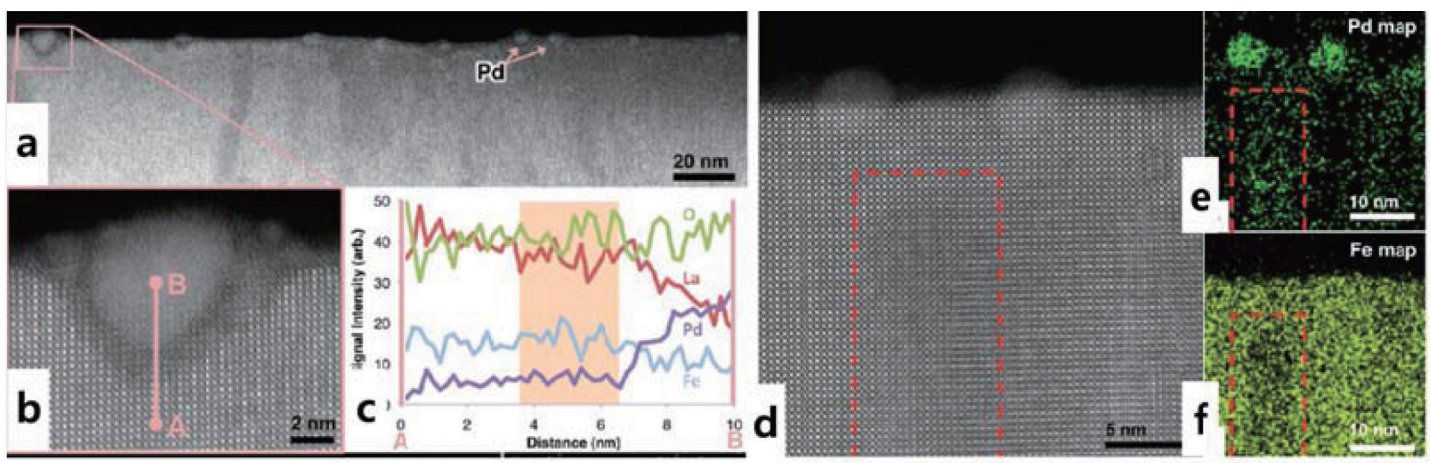

Fig. 3. a Pd/LaFeO ${ }_{3}$ 의 HAADF-STEM 이미지;; b 부분적으로 지지 촉매와 결합된 PdO 입자의 확대된 이미지 및 c EELS; d 용출된 $\mathrm{Pd} / \mathrm{LaFeO}_{3}$ 의 HAADF-STEM 이미지; e Pd; $\mathrm{f} \mathrm{Fe}$ 의 EDS mapping 결과.1)

잘 형성되지 않았다. 또한, Fig. $2 b$ 에서 $(110,104)$ 는 페 로브스카이트의 rhombohedral 구조를, (110)은 cubic 구조를 나타내며, $\mathrm{Ni}$ 의 도핑 농도 증가에 따라 구조의 변화가 확인되었다. XRD 피크의 shift를 통해 $5 \sim 10$ $\mathrm{mol} \%$ 도핑 사이에 셀 대칭의 변화를 보여주었다. 단위 셀 부피는 Fig. 2c에 보이는 바와 같이 $\mathrm{Ni}$ 도핑 양이 증 가함에 따라 작아졌고, 약 $7 \mathrm{~mol} \%$ 일 때 공간 그룹이 변 화함에 따라 셀 대칭의 변화가 관찰되었다. 이러한 결 과들은 XRD 분석이 금속의 용출 정도와 페로브스카이 트의 구조 변화에 대한 이해를 용이하게 함을 잘 보여준 다. ${ }^{19)}$

용출 입자 양이 적거나 사이즈가 $5 \mathrm{~nm}$ 보다 작을 때는 $\mathrm{XRD}$ 분석만으로는 명확한 관찰이 어렵다. 따라서, 에 너지 분산형 X-선 분광법 (Energy-Dispersive X-ray Spectroscopy, EDS)을 활용한 주사형 투과전자현미 경 (Scanning Electron Microscope, SEM) 또는 (주
사)투과전자현미경(Scanning Transmission Electron Microscopy, (S)TEM)을 통해 아주 작은 나노 사이즈의 용출된 입자를 검출해내야 한다. 전형적인 SEM 이미지 를 통해 초기에 합성된 페로브스카이트 표면에서는 용 출된 금속이 관찰되지 않았지만, 환원 처리 후에 용출된 나노 입자가 고르게 분산되어 있음을 확인할 수 있었다. 이 촉매에 산화 분위기를 다시 제공해주면 표면에 용출 된 금속 입자는 다시 벌크 격자로 이동하여 페로브스카 이트 표면에 입자가 관찰되지 않았다. ${ }^{20)}$

또한, 원자분해능 투과전자현미경으로 $\mathrm{Pd} / \mathrm{LaFeO}_{3}$ 의 재생(regeneration)도 명확하게 입증하였다. Fig. $3 \mathrm{a} \sim \mathrm{b}$ 처럼 $\mathrm{Pd}$ 입자가 $\mathrm{LaFeO}_{3}$ 에 부분적으로 지지 촉매 와 결합된 것을 분명하게 볼 수 있다. Electron Energy Loss Spectroscopy (EELS)에 의해 얻어진 Fig. 3b 에서 라인 $\mathrm{A} \rightarrow \mathrm{B}$ 에 따라 원소 이동이 관찰되었다(Fig. 3c). $\mathrm{EELS}$ 결과에서 $\mathrm{LaFeO}_{3}$ 의 지지 촉매 상과 가까울

a

b
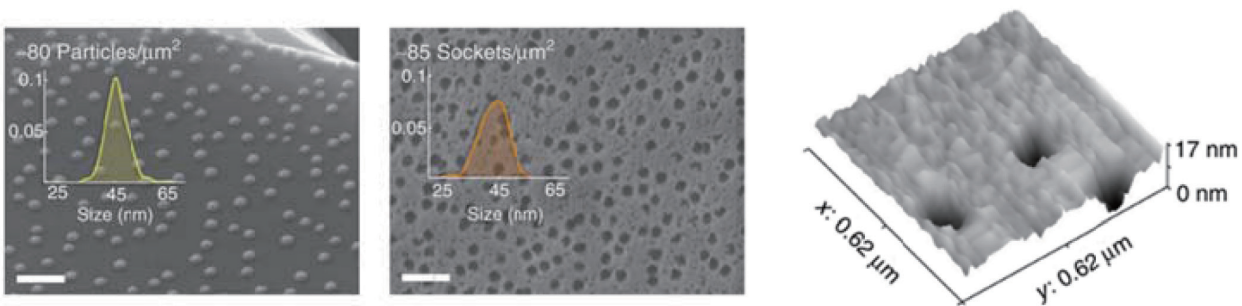

Fig. 4. a 용출된 촉매를 $\mathrm{HNO}_{3}$ 으로 식각 전(left)과 후(right); b 4a(right)와 유사한 식각된 표면의 3차원 $\mathrm{AFM}$ 이미지. ${ }^{13)}$ 
a

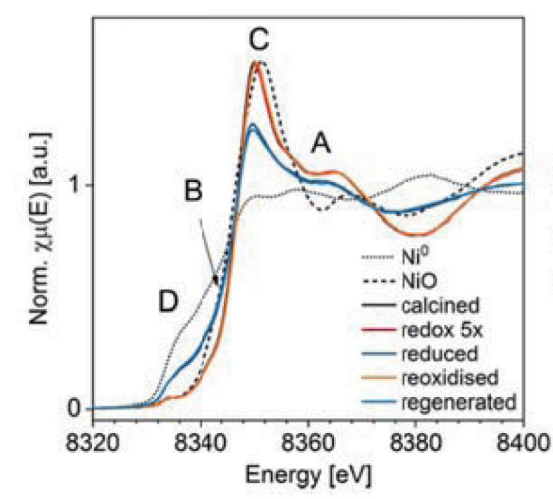

b

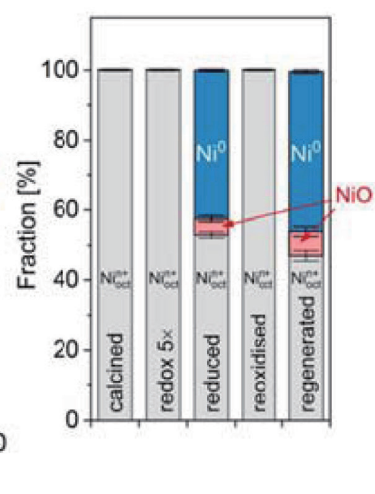

C

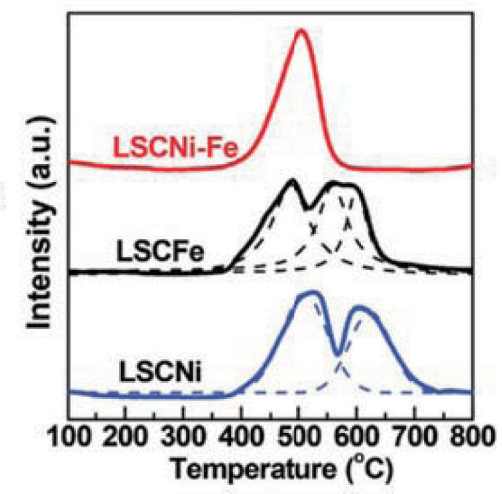

Fig. 5. a Ni k-edge(8333 eV)의 XANES 결과; b 5a 스펙트라에 대한 LCF 분석:22) c LSCNi, LSCFe, LSCNi-Fe 각각 촉매에 대한 $\mathrm{H}_{2}$-TPR profiles. ${ }^{23)}$

수록(A) Fe, La 비율이 높아지며, 반대로 표면 쪽으로 (B) 갈수록 $\mathrm{Pd}$ 비율이 높아진다. 또한, $\mathrm{EDS}$ mapping (Fig. 3d f)을 통해 페로브스카이트 구조 내에서의 (side view) $\mathrm{Pd}$ 분포를 확인할 수 있었다. $\mathrm{Pd}$ 는 페로 브스카이트 격자에서 $\mathrm{Fe}$ 를 치환하기 때문에, $\mathrm{Pd}$ 영역 에 위치한 $\mathrm{Fe}$ 는 상대적으로 낮은 농도로 존재하는 것 이 관찰되었다. 이와 같이 전자현미경을 통해 고온 산 화 및 환원 조건 하에서 $\mathrm{Pd}$ 가 $\mathrm{LaFeO}_{3}$ 벌크로 용해되고, $\mathrm{LaFe}_{0.95} \mathrm{Pd}_{0.05} \mathrm{O}_{3}$ 에서 표면으로 용출하는 현상이 명확하 게 증명되었다. ${ }^{21)}$

더 나아가, 용출된 입자가 실제로 표면에 소켓처럼 위치하고 있다는 사실도 Atomic Force Microscopy (AFM) 분석을 통해서 확인할 수 있었다. $\mathrm{HNO}_{3}$ 을 이
용하여 표면에 용출된 입자를 식각함으로써 확인되 었으며, 용출된 입자 크기와 식각 후 생성된 웅덩이 (sockets)의 크기 분포가 유사할 뿐만 아니라, 그 밀도 까지 $\sim 80$ particles $/ \mu \mathrm{m}^{2}$ 와 $\sim 85$ sockets $/ \mu \mathrm{m}^{2}$ 로 비슷 하였다 (Fig. 4a). AFM을 통한 식각된 표면의 확대된 이미지는 Fig. 4b에 도시되어 있으며, 용출된 금속이 모 체 산화물 지지체의 표면에서 상당한 깊이로 결합되어 있음을 나타낸다. ${ }^{13)}$

더 정밀한 원소의 산화 상태를 확인하기 위하여 X선 흡수 미세구조분석 (X-ray Absorption Fine Structure, XAFS) 및 $\mathrm{H}_{2}-\mathrm{TPR}$ 이 활용될 수 있다. $\mathrm{LaFe}_{0.8} \mathrm{Ni}_{0.2} \mathrm{O}_{3}$ 에 $\mathrm{Ni}$ 원소의 $\mathrm{K}$-edge 에너지 스펙트라 결과는, 초기 합성 된 페로브스카이트(Fig. 5a calcined)에 대부분의 $\mathrm{Ni}$ 은 a

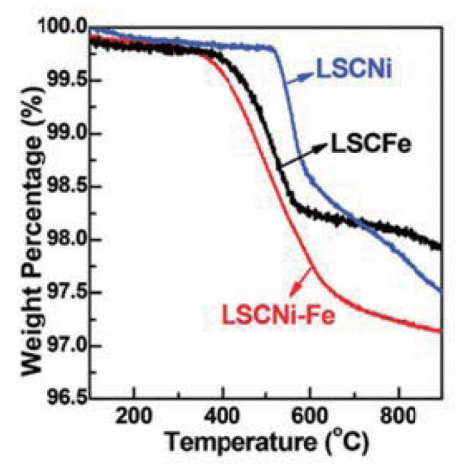

b

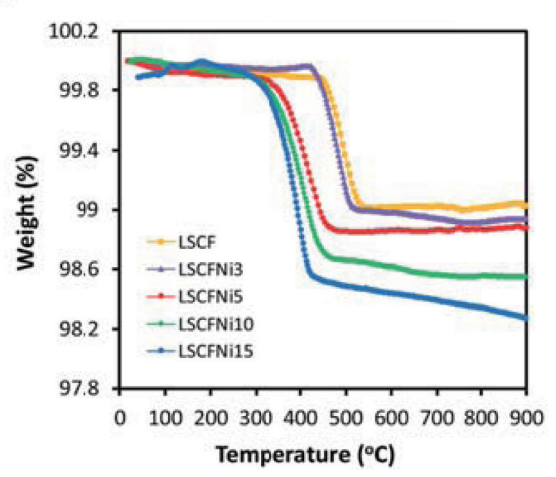

Fig. 6. a 합성된 LSCNi, LSCFe 및 LSCNi-Fe 샘플의 TGA의 결과 $\left(5 \% \mathrm{H}_{2} / \mathrm{N}_{2}\right)$; b LSCFNi 촉매의 TGA $\left(5 \% \mathrm{H}_{2} / \mathrm{Ar}\right)$. 
$\mathrm{Ni}^{2+}$ 보다 더 높은 산화 상태 $\left(\mathrm{Ni}^{\mathrm{n}+}(\mathrm{n}>2)\right)$ 로 존재하는 것으로 확인되며, 환원된 샘플은(Fig. $5 \mathrm{a}$ reduced) $\mathrm{Ni}^{0}$ 도 표면에 공존하는 것으로 확인되었다. 추가적으로, 재 산화 처리(Fig. 5 a reoxidised)를 해 줌에 따라, $\mathrm{Ni}$ 의 산 화수는 가역적으로 다시 초기 샘플(Fig. 5a calcined) 상태로 변화하였다. Linear combination fitting (LCF) (Fig. 5b)을 통해 처리 조건에 따른 $\mathrm{Ni}$ 산화수의 상대 적인 비율을 확인할 수 있었으며, 환원된 촉매(Fig. $5 \mathrm{a}$ reduced, regenerated)의 표면에서 금속성 $\mathrm{Ni}$ 의 비율 이 크게 늘어나는 것이 관찰되었다. 이와 같이 산화 환 원 처리 조건에 따른 용출 원소의 산화 상태의 가역성을 확인할 수 있었다. ${ }^{22)}$ Fig. 5 c LSCNi, LSCFe, LSCNi$\mathrm{Fe}$ 각각 촉매에 대한 $\mathrm{H}_{2}-\mathrm{TPR}$ profiles에서 단일 금속 용출인 경우, 용출 원소에 따라 수소 소모 피크는 두 개 또는 세 개로 나뉘어 관찰된 반면, $\mathrm{Ni}-\mathrm{Fe}$ 합금은 두 가 지 금속산화물이 동시에 환원되기 때문에 한 개의 수소 소모 피크가 관찰된다. 이를 통해, 용출된 입자가 단일 금속이 아닌 바이메탈릭(bimetallic)한 촉매인 것이 확 인되었다. ${ }^{23)}$

수소 분위기에서 실행하는 TGA (Thermogravimetric Analysis)는 금속산화물의 산소 공공(oxygen vacancy) 의 형성 유무를 무게 차이로 확인할 수 있다. Fig. $6 \mathrm{a}$ 에서 $\mathrm{LSCFNi}-\mathrm{Fe}$ 의 총 무게 감소 비율은 $\mathrm{LSCFe}$ 및 $\mathrm{LSCNi}$ 에 비해 상당히 높다. 이 결과는 $\mathrm{Ni}-\mathrm{Fe}$ 합금 의 형성이 산소 공공의 형성을 촉진한다는 것을 나타낸 다. ${ }^{24)}$ 또한, Fig. $6 \mathrm{~b}$ 와 같이 $\mathrm{LSCF}$ 의 $\mathrm{Ni}$ 도핑 농도와 그
용출 온도와의 관계가 확인되었다. $\mathrm{Ni}$ 도핑 농도가 높아 지면 환원이 더 낮은 온도에서 발생하여 금속의 용출 현 상이 잘 발현된다. ${ }^{19)}$ 이러한 TGA 분석은 촉매의 최소 환원 온도를 확인하기에 매우 적합하다고 할 수 있다.

\section{3. 기상 반응의 응용}

용출된 촉매가 기상 반응으로써 최초로 활용된 것은 배기가스 저감을 위한 가솔린 차량의 삼원촉매 (ThreeWay Catalytic, TWC) 변환기이다. 내연 기관에서 방 출되는 배기가스는 주로 미연소 탄화수소(UHC), 일산 화탄소 $(\mathrm{CO})$ 및 질소 산화물 $\left(\mathrm{NO}_{\mathrm{x}}\right)$ 과 같은 유해 가스이 다. ${ }^{25)}$ 엄격한 배출 수준 준수와 환경 보호를 위해서, 이 들 오염 물질들은 주변 환경으로 방출되기 전에 제거 되어야 한다. 이 배출가스 제어 장치는 모놀리식 허니 컴 기판상에 장착된 촉매 활성 성분의 혼합물로 구성되 어 있다. 이를 통해 $\mathrm{UHC}, \mathrm{CO}$ 및 $\mathrm{NO}_{\mathrm{x}}$ 를 무해한 $\mathrm{CO}_{2}$, $\mathrm{H}_{2} \mathrm{O}$ 및 $\mathrm{N}_{2}$ 로 동시에 전환 할 수 있게 한다. 산화 및 환 원 반응이 동시에 발생해야 하기 때문에, 화학양론 지 점에 가까운 조건(즉, 가솔린 차량의 경우 공연비 14.7 $\mathrm{w} / \mathrm{w}$ )에서 작동 할 때 $\mathrm{TWC}$ 가 가장 효율적이다. ${ }^{27)}$ 배 기 가스의 조성은 산소 센서에 의해 연속적으로 결정되 고, 공연비는 연료 제어 피드백 시스템에 의해 조절된 다. 이러한 과정은 Fig. $7 \mathrm{a}$ 에 보여주는 바와 같이 변환 기에서 산화 또는 환원 조건으로 교차되어 존재하기 때 문에 산화 환원 조건에 활성적이고 안정적인 촉매가 필 a

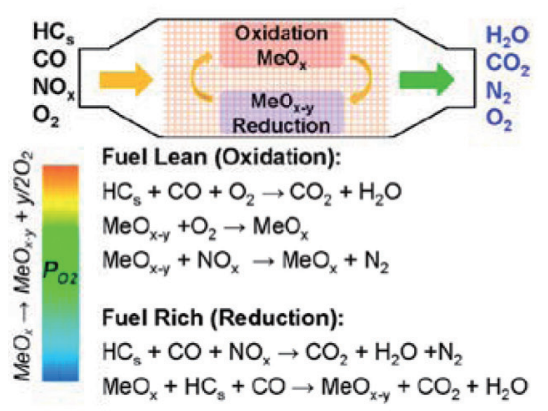

b

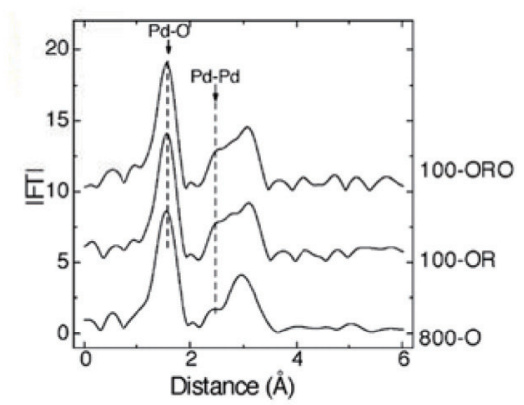

C

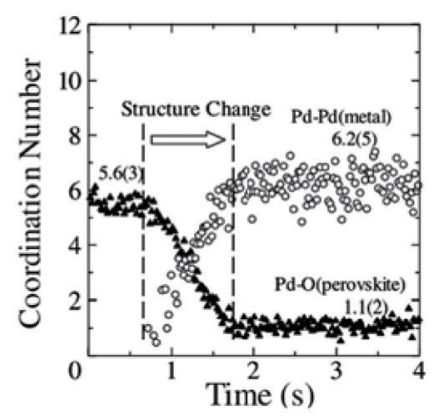

Fig. 7. $a$ 페로브스카이트 기반한 용출 촉매의 Three-way catalyst (TWC) 응용 개략도 $\left(\mathrm{MeO}_{x}\right.$ : 합성된 촉매, $\mathrm{MeO}_{x-y}$ 용출된 촉매);25) $\mathrm{b} 400{ }^{\circ} \mathrm{C}$ 에서 $\mathrm{LaFe}_{0.95} \mathrm{Pd}_{0.05} \mathrm{O}_{3}$ 의 $\mathrm{k}^{3} \mathrm{X}(\mathrm{k})$ 프리에변환 ${ }^{28)}$; c $400{ }^{\circ} \mathrm{C}$ 에서 $\mathrm{Pd}-\mathrm{O}$ 결합 및 $\mathrm{Pd}-\mathrm{Pd}$ 결합의 배위수와 시간과의 상관관계. ${ }^{26)}$ 
요하다. ${ }^{25)}$ 2002년, Toyota 그룹의 다이하츠 모터스는 처음으로 “intelligent catalyst”인 $\mathrm{Pd}$ 가 용출된 페로브 스카이트 촉매 $\left(\mathrm{LaFe}_{0.57} \mathrm{Co}_{0.38} \mathrm{Pd}_{0.05} \mathrm{O}_{3}\right)$ 를 개발하고 상용 화하였다. ${ }^{1)}$ 특히, $\mathrm{Pd}$ 가 용출될 수 있는 환원 처리 조건 은 $100{ }^{\circ} \mathrm{C}$ 의 아주 낮은 온도임에도 불구하고, $\mathrm{Pd}^{0}$ 종은 $\mathrm{LaFe}_{0.95} \mathrm{Pd}_{0.05} \mathrm{O}_{3}$ 의 $\mathrm{B}$-사이트로부터 촉매 표면상에 부분 적으로 석출되기 시작되었다. 용출된 $\mathrm{Pd}^{0}$ 종은 연속적인 산화 분위기에 의해 $200{ }^{\circ} \mathrm{C}$ 부터 표면에 $\mathrm{Pd}^{0}$ 는 $\mathrm{Pd}^{2+}$ 로 재산화가 시작되었다. 표면 $\mathrm{Pd}^{2+}$ 는 부분적으로 페로브 스카이트 프레임(frame)으로 용해되어 B-사이트를 점 유하였다 (Fig. 7b). ${ }^{28)}$ 더 나아가, $\mathrm{Pd}$ 원소의 용출되는 과정을 직접적으로 확인하기 위해, 산화 환원 분위기 변 화에 의한 $\mathrm{Pd}$ 주변의 국소 구조(local structure)의 시 간에 따른 변화를 in situ energy-Dispersive X-ray
Absorption Fine-Structure (in situ-DXAFS)로 조 사하였다 (Fig. 7c). ${ }^{26)}$ 이를 통해 $\mathrm{Pd}$ 의 구조 변화는 실제 가솔린 엔진의 제어 주파수(1 4Hz)에 응답하기에 충 분히 빠르며, 용출된 $\mathrm{Pd}$ 입자가 매우 미세하다는(약 0.8 $\mathrm{nm}$ ) 것을 증명했다. 이러한 self-regeneration은 $\mathrm{Pd}$ 뿐만 아니라 다른 귀금속에도 (Pt, Rh 등) 활용할 수 있 다는 것도 확인되었다. ${ }^{29-30)}$ 이로부터 시작된 용출 촉매 의 기상 반응으로의 적용은 일반적으로 두 가지 특성이 활용된다. 첫번째는 용출된 입자는 표면과 벌크 격자 사 이를 가역적으로 이동함에 따라 반응의 불활성화를 유 도할 수 있는 물질이 강하게 흡착되어도 촉매를 계속 활 용할 수 있도록 하는 “재생(regeneration)" 특성이다. 이러한 특성은 종래의 방법으로 함침된 촉매의 응집 현 상 및 카본, $\mathrm{SO}_{2}$ 으로 인한 피독 현상을 방지할 수 있다.

\section{a}

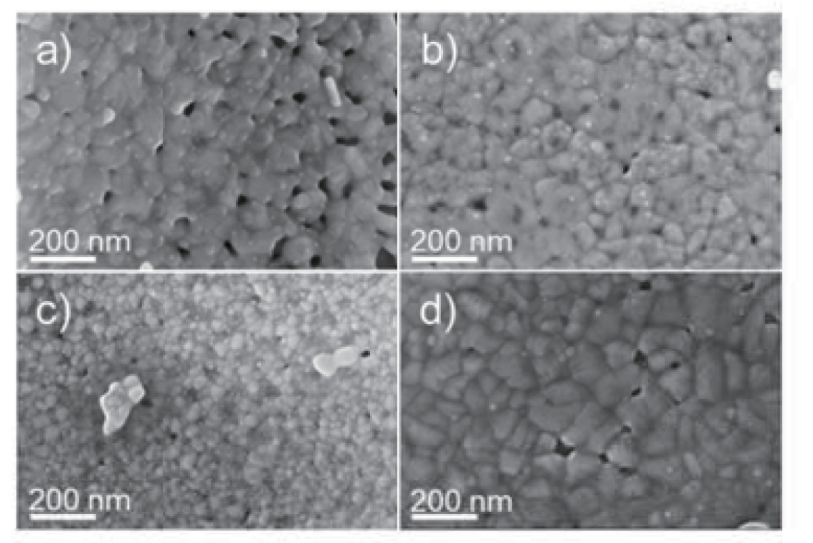

\section{C}
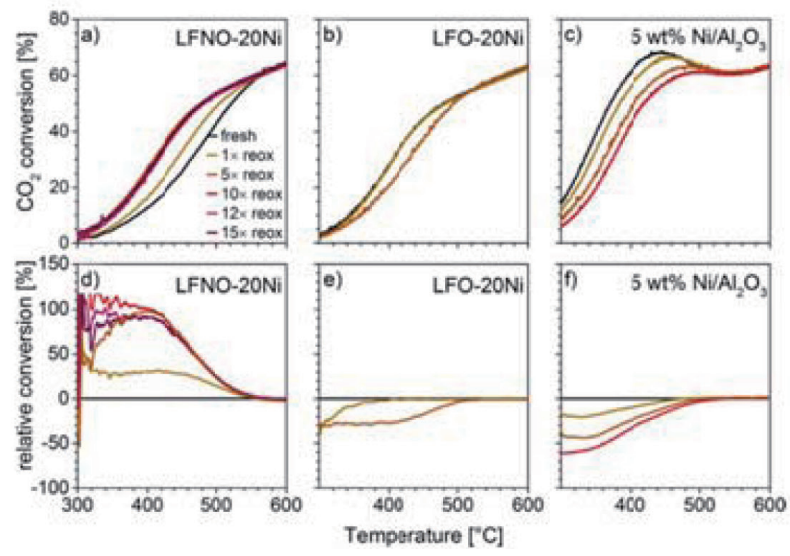

b

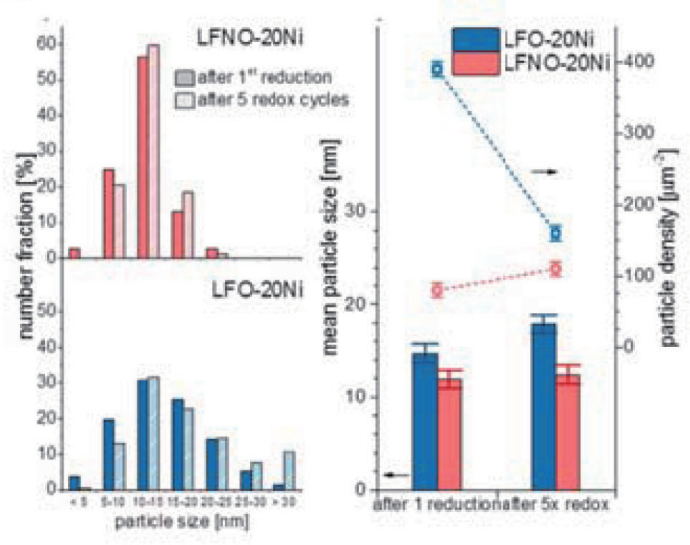

Fig. 8. a LFNO-20Ni의 SEM 이미지 a) 초기 환원 후, b) 5 번 redox 후, LFO-20Ni의 SEM 이미지 c) 초 기 환원 후, d) 5번 redox 후; b (left) LFNO-20Ni 및 LFO-2ONi은 초기 환원 및 5번 redox 후 $\mathrm{Ni}$ 입 자 크기 분포, (right) 평균 입자 크기 및 입자 밀도; C $\mathrm{CO}_{2}$ 전환율 a) LFNO-20Ni, b) LFO-20Ni, c) $5 \mathrm{wt} \% \mathrm{Ni} / \mathrm{Al}_{2} \mathrm{O}_{3}$ 및 초기 환원 후 샘플의 $\mathrm{CO}_{2}$ 전환 율에 대한 변화, d) LFNO-2ONi, d) LFO-2ONi, f) $5 \mathrm{wt} \% \mathrm{Ni} / \mathrm{Al}_{2} \mathrm{O}_{3}{ }^{23)}$ 
a

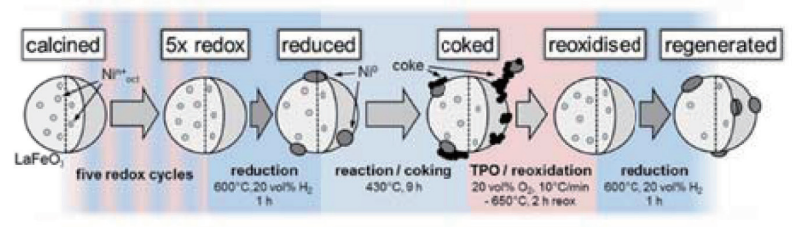

b

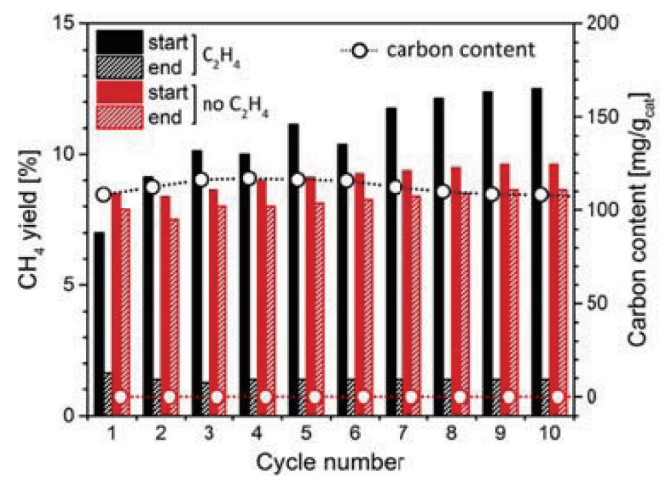

Fig. 9. a LaFe ${ }_{0.8} \mathrm{Ni}_{0.2} \mathrm{O}_{3}$ 에 대한 연속적인 산화 환원 처리; b 열 번의 reaction-coking-regeneration cycle을 걸친 $\mathrm{CH}_{4}$ yield. ${ }^{22)}$

두번째는 용출된 입자의 강한 anchoring 현상을 이용하 여 입자의 반응성을 촉진시키고, 벌크에 위치되어 있는 금속이 표면으로 이동됨 따라 활성 사이트를 증가시켜 활성을 향상시킬 수 있다는 특성이 활용된다.

페로브스카이트 기반 용출 촉매는 피독 또는 입자 성 장으로 인한 비활성화 후에도 재생이 가능하므로 산화환원 안정성의 현저한 이점을 제공한다. Ferri 연구진 은 용출 입자의 가역적인 특성을 활용하여 이산화탄소 $\left(\mathrm{CO}_{2}\right)$ 의 수소 첨가 반응 $\left(\mathrm{CO}_{2}\right.$ hydrogenation $)$ 에 적용하 였다. 용출 촉매인 $\mathrm{Ni} / \mathrm{LaFeNiO}_{3-\delta}(\mathrm{LFNO}-20 \mathrm{Ni})$ 은 종 래의 방법으로 함침한 촉매인 $\mathrm{Ni} / \mathrm{LaFeO}_{3-\delta}(\mathrm{LFO}-20 \mathrm{Ni})$ 와 $\mathrm{Ni} / \mathrm{Al}_{2} \mathrm{O}_{3}$ 의 비교를 통해 촉매 성능의 우위를 보여주 었다. 금속 용출을 위한 초기 환원 후에, 5 번의 산화환원 사이클(redox cycle) 이 수행되어도 LFNO-20Ni 는 $\mathrm{Ni}$ 평균 입자 크기 및 입자 밀도에 있어 큰 차이를 보 이지 않았다 (Fig. 8a-a) b)). 반면, 함침시킨 LFO$20 \mathrm{Ni}$ 의 경우, 산화-환원 주기 횟수에 의해 크게 영향 을 받았다 (Fig. $8 \mathrm{a}-\mathrm{c}$ ) d ) ). ${ }^{23)}$ 초기 반응 시 합성된 세 촉매 중 용출된 LFNO- $20 \mathrm{Ni}$ 촉매는 가장 낮은 $\mathrm{CO}_{2}$ 전 환율을 나타냈지만, 산화-환원 사이클이 수행됨에 따라 용출의 양이 증가하여 활성이 크게 개선되었고, 높은 활 성이 장기간 유지되었다. 초기 환원 후 샘플의 $\mathrm{CO}_{2}$ 전 환율의 증가는 5 사이클의 산화-환원주기에서 약 $100 \%$ 이었다 (Fig. $8 \mathrm{c}$ ). 이 샘플과 대조적으로, 함침된 촉매인 $\mathrm{Ni} / \mathrm{Al}_{2} \mathrm{O}_{3}$ 및 $\mathrm{LFO}-20 \mathrm{Ni}$ 는 산화-환원 사이클이 반복됨
에 따라 활성 저하를 나타냈다. 이러한 결과들은 용출된 촉매의 가역성 및 응집 방지 효과를 입증한다. ${ }^{23)}$ 더불 어, 페로브스카이트 $\mathrm{LaFe}_{0.8} \mathrm{Ni}_{0.2} \mathrm{O}_{3}$ 의 $\mathrm{A}$-사이트인 $\mathrm{La}$ 에 $\mathrm{Sr}$ 을 부분 치환하였을 때, 표면으로 더 많은 $\mathrm{Ni}$ 금속이 용출되어 $\mathrm{CO}_{2}$ 메탄화반응 $\left(\mathrm{CO}_{2}\right.$ methanation)의 활성 이 개선되었다 (최대 50\%). 또한, 재산화 과정 동안 부 분 치환된 $\mathrm{Sr}$ 은 $\mathrm{Ni}$ 의 페로브스카이트 벌크 격자로의 재 이동을 방해하지 않았다. 따라서, 페로브스카이트 $\mathrm{A}$-사 이트인 $\mathrm{La}$ 에 $\mathrm{Sr}$ 의 부분 치환은 $\mathrm{Ni}$ 입자의 용출을 촉진 시켜 촉매 활성 향상에 활용할 수 있는 전략으로 생각될 수 있다. ${ }^{31)}$

또한, 페로브스카이트의 용출 현상을 이용해 $\mathrm{CO}_{2}$ 의 메탄화반응에서 탄소 피독 문제를 성공적으로 해결하였 다. 잘 알려진 바와 같이 전통적인 함침으로 제조된 촉 매는 탄소 피독으로 인한 촉매 불활성화를 억제하기 어 려웠다. 일반적으로 이러한 피독된 촉매를 재활성화 시 키기 위해서 고온 산화 $(\mathrm{Ni}$ 표면에 침전된 탄소를 연소 하면서 제거된다)-환원(탄소 제거 후 산화된 니켈 입자 를 다시 니켈 메탈로 환원한다) 사이클로 처리한다. 그 러나 이에 따른 $\mathrm{Ni}$ 입자의 sintering 문제가 야기되기도 한다. Ferri 연구진은 $\mathrm{LaFe}_{0.8} \mathrm{Ni}_{0.2} \mathrm{O}_{3}$ 에 용출된 $\mathrm{Ni}$ 촉매 를 활용하여 표면 탄소 피독을 효과적으로 제거하고 촉 매의 재생을 입증하였다. 환원 조건에서 $\mathrm{Ni}$ 은 페로브스 카이트 산화물의 격자에서 표면으로 용출되며, 산화 조 건에서 표면에 존재하던 $\mathrm{Ni}$ 의 페로브스카이트 격자로의 
a

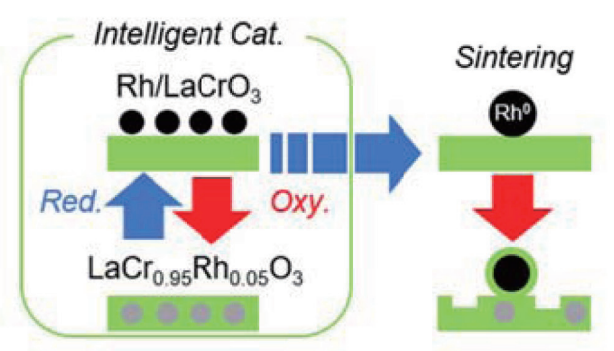

b

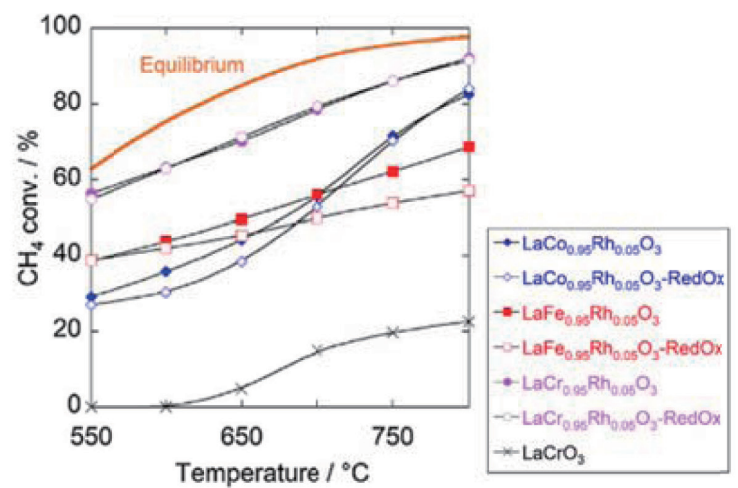

Fig. 10. a $\mathrm{LaCr}_{0.95} \mathrm{Rh}_{0.05} \mathrm{O}_{3}$ 용출 촉매의 $\mathrm{CH}_{4}$ partial oxidation에 응용 모식도; b $\mathrm{LaM}_{0.95} \mathrm{Rh}_{0.05} \mathrm{O}_{3}$ 및 $\mathrm{LaCrO}_{3}$ 의 $\mathrm{CH}_{4}$ 전환율. ${ }^{32)}$

손실 없는 이동이 가역적으로 발생되는 것을 확인하였 다 (Fig. $9 \mathrm{a} \sim \mathrm{b}){ }^{22)}$ 이러한 현상은 표면에 형성된 탄소를 효과적으로 제거하고, 이에 따라 촉매의 불활성화를 억 제하였다. ${ }^{22)}$

셰일 가스(shale gas) 혁명이 일어난 후, 천연 가스 (주성분: $\mathrm{CH}_{4}$ )를 고급 탄화수소 및 산소첨가제와 같 은 합성 가스와 반응시켜 유용한 제품으로 전환하는 것 이 매우 중요해졌다. 특히, $\mathrm{CH}_{4}$ 부분 산화는 발열 특성 이므로 외부 열 공급이 필요하지 않을 뿐만 아니라, 생 성된 합성 가스는 $\mathrm{H}_{2}$ 와 $\mathrm{CO}$ 로 구성되어 이론 몰비가 2 로, Fischer-Tropsch 합성에 적합하다. 그러나, 부분 산화 발열 반응은 촉매 층에서 핫스팟을 생성하여 활 성 종의 소결과 같은 촉매의 열화를 초래한다. 또한, 반 응물에서 고농도의 $\mathrm{C}$ 종으로 인해, 촉매 표면상의 탄
소 피독에 의해 촉매가 불활성화 될 수 있다. Kikuchi 연구진은 $\mathrm{LaM}_{0.95} \mathrm{Rh}_{0.05} \mathrm{O}_{3}(\mathrm{M}: \mathrm{Cr}, \mathrm{Co}, \mathrm{Fe})$ 를 합성하 고, 이에 촉매 활성을 보존하기 위한 재생 특성을 부여 하기 위해 산화-환원 처리 조건을 이용하였다. 이 중에 서 $\mathrm{LaCr}_{0.95} \mathrm{Rh}_{0.05} \mathrm{O}_{3}$ 는 가장 높은 $\mathrm{CH}_{4}$ 전환율을 나타냈 다 (Fig. $10 \mathrm{a} \sim \mathrm{b})$. 그 이유는 다음과 같은 세 가지 요인 으로 생각할 수 있다. 첫째는 지지체 촉매로 이용된 페 로브스카이트가 금속 용출을 위한 산화-환원 조건 하에 서 갖는 구조적 안정성이다. 반면에, $\mathrm{LaCo}_{0.95} \mathrm{Rh}_{0.05} \mathrm{O}_{3}$ 는 고온을 수반하는 환원 분위기에서 본래 구조가 붕 괴됨에 따라 낮은 활성이 관찰되었다. 두번째 요인 은 활성 사이트(용출된 $\mathrm{Rh}^{0}$ 사이트) 수의 차이이다. $\mathrm{LaCr}_{0.95} \mathrm{Rh}_{0.05} \mathrm{O}_{3}$ 및 $\mathrm{LaFe}_{0.95} \mathrm{Rh}_{0.05} \mathrm{O}_{3}$ 에 용출된 $\mathrm{Rh}^{0}$ 사이 트 수는 $\mathrm{LaCo}_{0.95} \mathrm{Rh}_{0.05} \mathrm{O}_{3}$ 보다 많았다. 마지막 요인은 촉 a

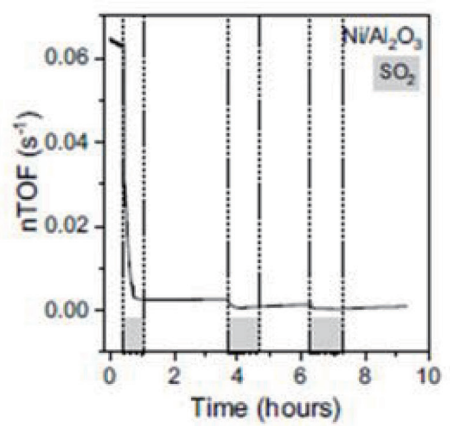

b

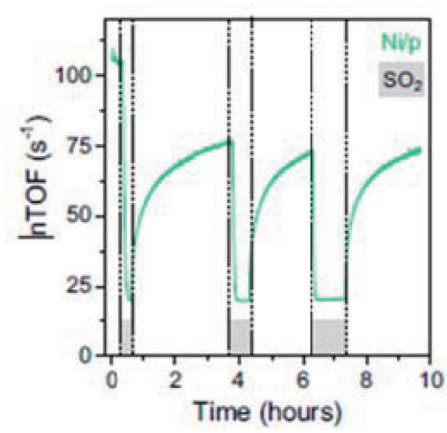

C

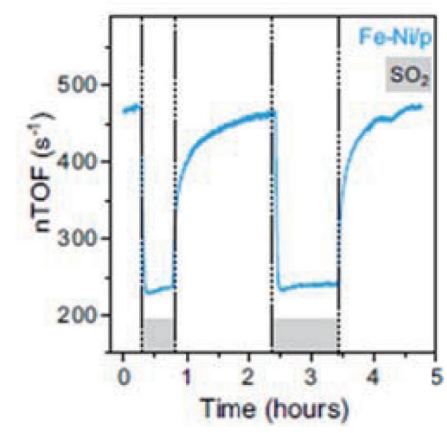

Fig. 11. $\mathrm{SO}_{2}$ 노출 시 nTOF 값 a Ni/Al $\mathrm{O}_{3}, \mathrm{~b} \mathrm{Ni} / \mathrm{p}, \mathrm{c} \mathrm{Fe}-\mathrm{Ni} / \mathrm{p}^{33)}$ 
a

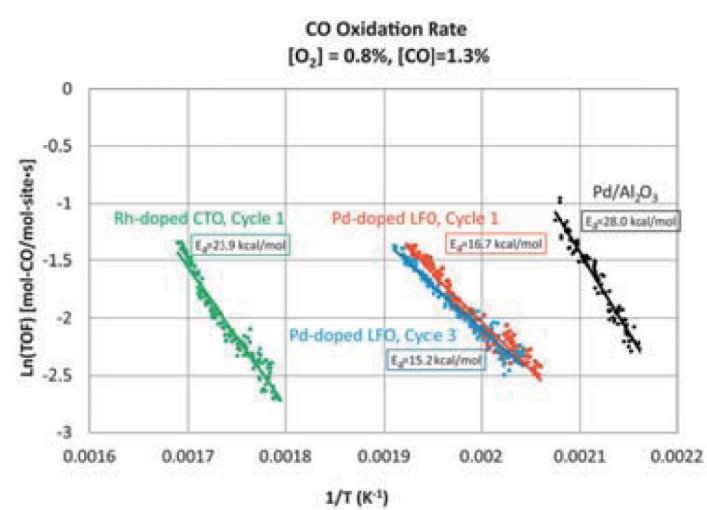

C

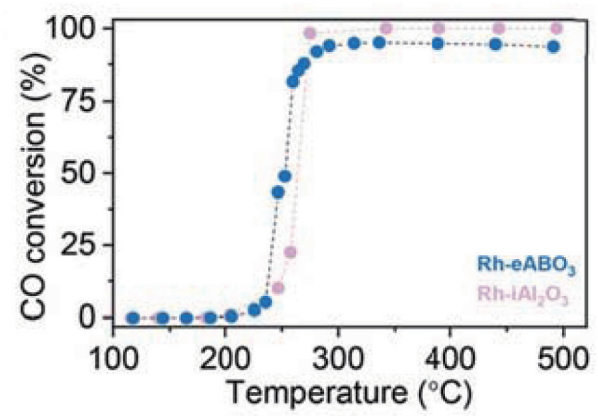

매 표면에 형성된 활성 산소 종으로 추정된다. $\mathrm{LaCrO}_{3}$ 는 $\mathrm{LaFeO}_{3}$ 보다 더 약하게 화학 흡착된 산소 종을 갖는 다. ${ }^{32}$

니켈 기반 촉매는 황 화합물에 매우 취약한 것으로 알 려져 있으며, 심지어 몇 $\mathrm{ppm}$ 의 황에 의해서도 극심한 촉매의 피독을 일으킬 수 있다. 황 피독의 영향을 연구 하기 위해, $0.6 \mathrm{ppm} \mathrm{CO}$ 및 $1 \% \mathrm{O}_{2}$ 의 기체 혼합물에 50 $\mathrm{ppm} \mathrm{SO}_{2}$ 를 15,30 및 60 분 동안 순차적으로 첨가하 고, nTOF를 기록하였다 (Fig. 11). $\mathrm{SO}_{2}$ 노출 후, 상용 $\mathrm{Ni} / \mathrm{Al}_{2} \mathrm{O}_{3}$ 촉매는 nTOF 값이 약 $95 \%$ 로 급격하게 감소 한 것으로 확인되었다. 공급물로부터 $\mathrm{SO}_{2}$ 를 제거한 후 에도, nTOF 값은 회복되지 못하고 낮은 상태로 유지 되었다 (Fig. 11a). 동일한 조건 하에서, $\mathrm{Ni} / \mathrm{p}$ 촉매의 $\mathrm{nTOF}$ 값은 $83 \%$ 로 감소하였고, $\mathrm{SO}_{2}$ 가 공급물로부터 제거되었을 때, nTOF 값은 초기 값의 약 $68 \%$ 로 부분적 으로 회복되었다 (Fig. 11b). 흥미롭게도, $\mathrm{F}-\mathrm{Ni} / \mathrm{p}$ 촉매 b

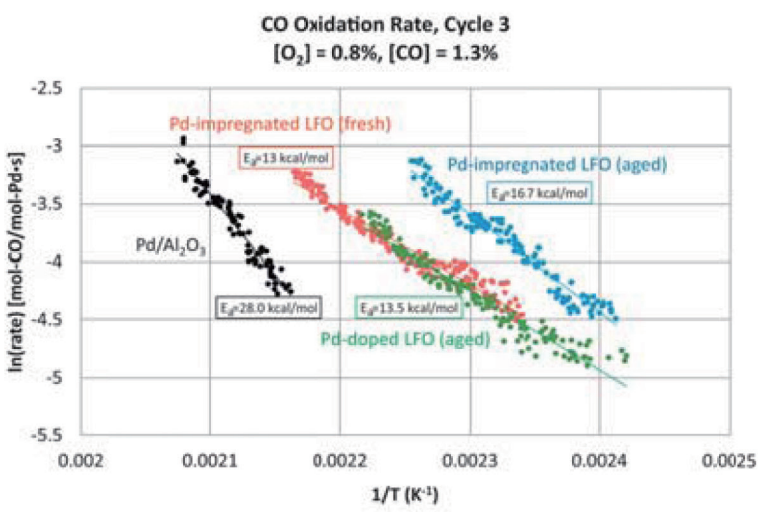

Fig. 12. a Rh-doped CTO (green), Pd-doped LFO (red), Pddoped LFO 및 $\mathrm{Pd} / \mathrm{Al}_{2} \mathrm{O}_{3}$ (black)의 $\mathrm{CO}$ oxidation rate (TOF로 표현); b aged Pd-doped LFO (green), Pdimpregnated LFO (blue) 및 $\mathrm{Pd} / \mathrm{Al}_{2} \mathrm{O}_{3}$ (black)의 $\mathrm{CO}$ oxidation rate. ${ }^{34)} \mathrm{c}$ 온도에 따른 $\mathrm{CO}$ 의 전환율. ${ }^{35)}$

는 동일한 조건 하에서, $\mathrm{SO}_{2}$ 노출 동안 $\mathrm{TOF}$ 가 $50 \%$ 감 소하였지만, 공급물로부터 $\mathrm{SO}_{2}$ 를 제거한 후 초기 활성 의 대략 $98 \%$ 가 회복되었다(Fig. 11c). 이러한 결과들은 황 피독 시스템에서도 용출 촉매가 효과적으로 적용될 수 있음을 시사한다. ${ }^{33}$

용출 촉매를 $\mathrm{CO}$ 산화 반응에 적용 시, 종래의 합성 법으로 제조된 촉매의 활성과 비교하기 위하여 $\mathrm{Pan}$ 연 구진은 4 개의 고표면적을 갖는 $\left(50-60 \mathrm{~m}^{2} / \mathrm{g}\right)$ 페로브 스카이트 기반 분말 촉매를 사용하였다. $\mathrm{Pd}$ 이 도핑된 $\mathrm{LaFeO}_{3}\left(\mathrm{Pd}\right.$-doped LFO), $\mathrm{Pd}$ 이 함침된 $\mathrm{LaFeO}_{3}(\mathrm{Pd}-$ impregnated $\mathrm{LFO}$ ), Rh이 도핑된 $\mathrm{CaTiO}_{3}$ (Rh-doped $\mathrm{CTO}$ ) 및 $\mathrm{Rh}$ 이 함침된 $\mathrm{CaTiO}_{3}$ (Rh-impregnated $\mathrm{CTO})$ 의 초기 산화 및 산화-환원 aging $\left(800{ }^{\circ} \mathrm{C}\right.$ 에 서 14 시간) 조건에서의 활성 차이를 조사하였다 (Fig. $12 \mathrm{a} \sim \mathrm{b}){ }^{34)}$ 도핑된 촉매 활성은 함침된 촉매보다 초기 활성 낮았지만, aging 과정은 두 시스템의 촉매 성능을 
a

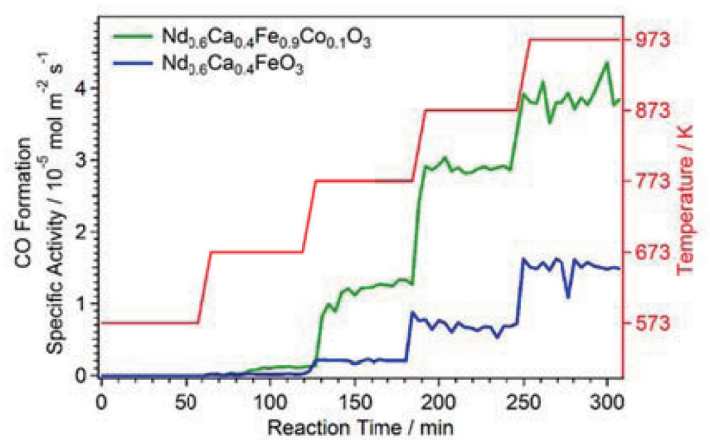

b

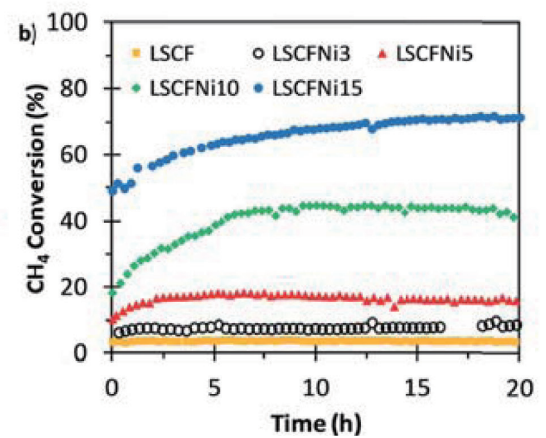

Fig. 13. a undoped (blue) 및 Co doping된 (green) 촉매의 rWGS 활성;1) b LSCFNi 촉매의 $\mathrm{CH}_{4}$ 전환율. ${ }^{19}$

향상시켰다. 이와 유사하게 페로브스카이트에 기반한 용출된 $\mathrm{Rh}$ 촉매와 종래의 $\mathrm{Rh} / \mathrm{Al}_{2} \mathrm{O}_{3}$ 촉매에서의 $\mathrm{CO}$ 산 화 반응 활성은 전반적으로 유사한 활성을 가졌지만, 저 온에서 소폭 높은 활성이 관찰되었다 (Fig. 12c). ${ }^{35)}$ 그 원인은 용출 입자가 함침 입자보다 더 큼에도 불구하고, $\mathrm{B}$-사이트에 치환된 $\mathrm{Rh}$ 의 일부만이 표면 위로 용출되 기 때문이라고 볼 수 있다. $\mathrm{CO}$ 산화 반응의 초기 활성을 높이려면 도핑 원소의 더 많은 용출 또는 용출된 입자의 크기 조절이 중요한 요소로 보인다.

환원성이 높은 원소로 $\mathrm{B}-$ 사이트를 도핑하면, 용출된 촉 매의 특성을 제어할 수 있는 장점이 있다. 역수성가스 전 환반응 (rWGS)에서, $\mathrm{Fe}$ 입자가 용출된 $\mathrm{Na}_{0,6} \mathrm{Ca}_{0.4} \mathrm{FeO}_{3-\delta}$ 촉 매와 $\mathrm{Co}$ 입자가 용출된 $\mathrm{Nd}_{0,6} \mathrm{Ca}_{0,4} \mathrm{Fe}_{0.9} \mathrm{Co}_{0,1} \mathrm{O}_{3-\delta}$ 촉매를 비 교하였다. $\mathrm{B}-$ 사이트로의 $\mathrm{Co}$ 도핑은 더 낮은 환원 온도
에서 표면상에 미세하게 분산된 Co 나노 입자를 형성시 켰다. 이러한 페로브스카이트형 촉매는 화학 에너지 전 환(예를 들어, $\mathrm{CO}_{2}$ 를 $\mathrm{CO}$ 로 전환하고 이어서 $\mathrm{CO}$ 의 수소 첨가반응을 통해 액체 연료인 디젤, 가솔린 및 알코올을 생산할 수 있다.) 적용하기에 매우 유망하다. $\mathrm{Co}$ 를 $\mathrm{B}-$ 사이트에 도핑한 후에 용출된 Co 나노 입자의 경우, B사이트에 도핑하지 않은 $\mathrm{Fe}$ 나노 입자를 용출시킬 때보 다 매우 작은 입자로 존재하기 때문에 rWGS에서 $\mathrm{CO}_{2}$ 전환에 대한 촉매 활성을 크게 향상시키는 것으로 나타 났다 (Fig. 13a). ${ }^{1)}$

$\left(\mathrm{La}_{0.75} \mathrm{Sr}_{0.25}\right)\left(\mathrm{Cr}_{0.5} \mathrm{Fe}_{0.5-\mathrm{x}} \mathrm{Ni}_{\mathrm{x}}\right) \mathrm{O}_{3}$ 페로브스카이트는 메 탄 개질 반응 촉매로도 조사되었다. 환원 처리에 의해 바이메탈릭 $\mathrm{Fe}-\mathrm{Ni}$ 합금 나노 입자가 페로브스카이트 촉매 표면에서 형성되었고, 이는 촉매의 활성에 크게 기 a

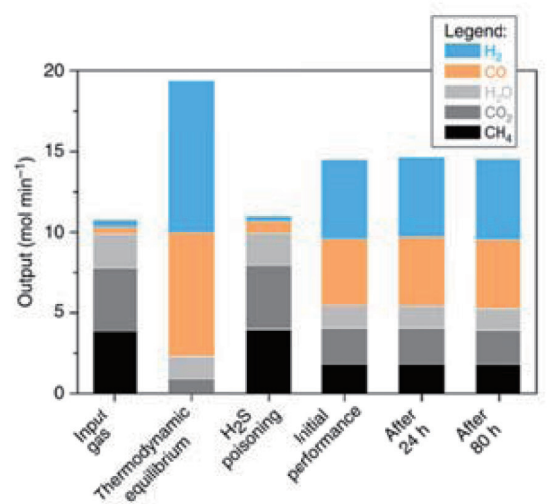

b

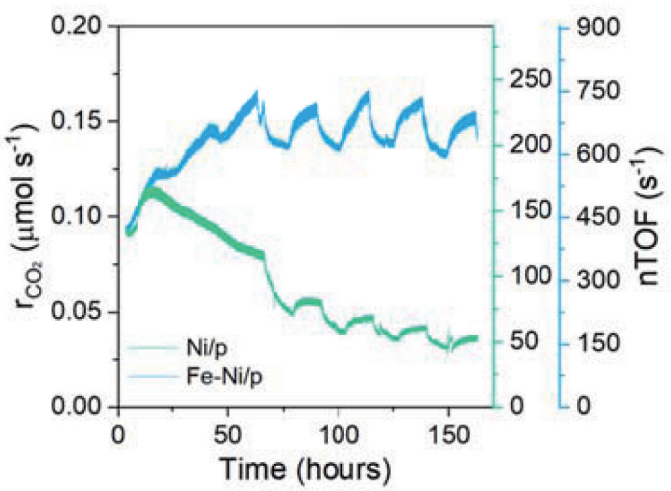

Fig. 14. a Ni 용출된 $\mathrm{La}_{0.52} \mathrm{Ca}_{0.28} \mathrm{Ni}_{0.06} \mathrm{Ti}_{0.94} \mathrm{O}_{3}$ 촉매의 reforming test 결과; ${ }^{\cdot 3)} \mathrm{b} \mathrm{Ni} / \mathrm{p}$ 및 $\mathrm{Fe}-\mathrm{Ni} / \mathrm{p}$ 촉매에 대한 시간에 따른 $\mathrm{CO}_{2}$ production rate. ${ }^{33)}$ 
a

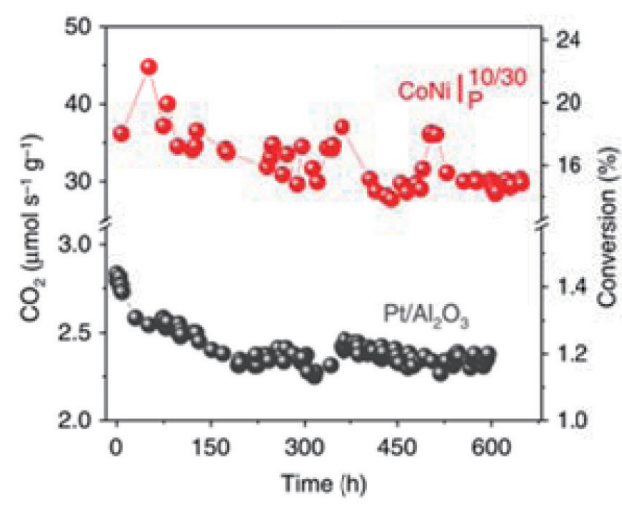

b

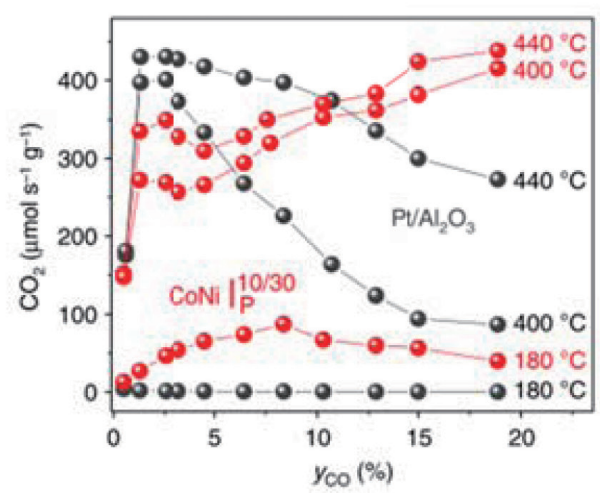

Fig. 15. a CoNi/P 및 $\mathrm{Pt} / \mathrm{Al}_{2} \mathrm{O}_{3}$ 촉매에 대한 $220^{\circ} \mathrm{C}, 650$ 시간 동안 $\mathrm{CO}_{2}$ production rate; b CO mole function에 따른 $\mathrm{CO}_{2}$ production rate.

여하였다 (Fig. 13b). ${ }^{19)}$ 활성이 가장 우수한 촉매의 화학 양론은 $\left(\mathrm{La}_{0.75} \mathrm{Sr}_{0.25}\right)\left(\mathrm{Cr}_{0.5} \mathrm{Fe}_{0.35} \mathrm{Ni}_{0.15}\right) \mathrm{O}_{3}$ 로 되어있으며, 이는 초기 $\mathrm{Ni}$ 의 도핑 없는 페로브스카이트 보다 20배 높 은 $\mathrm{CH}_{4}$ 전환율(72\%)을 나타냈다. Fig. $13 \mathrm{~b}$ 는 $900{ }^{\circ} \mathrm{C}$ 에 서 20시간 동안의 $\mathrm{CH}_{4}$ 의 전환율을 나타낸다. $\mathrm{Ni}$ 의 도핑 없는 $\mathrm{LSCF}$ 는 $\mathrm{CH}_{4}$ 의 낮은 전환률을 계속 유지하였다. 반면에, $\mathrm{Ni}$ 의 도핑을 증가시킴으로써 $\mathrm{CH}_{4}$ 전환율이 증 가하였고, 이를 통해 $\mathrm{Fe}-\mathrm{Ni}$ 합금 나노 입자가 $\mathrm{CH}_{4}$ 을 효 과적으로 전환할 수 있는 활성 사이트라고 보고하였다. 더욱이, 모든 물질은 $\mathrm{CH}_{4}$ 전환의 감소가 관찰되지 않았 고, 테스트하는 20시간 동안 매우 우수한 안정성을 나타 내었다.
용출된 입자의 강한 anchoring에 의해 상당히 개선 된 장기 안정성은 용출 촉매의 장점이라고 알려져 있다. Irvine 연구진은 페로브스카이트 산화물에 함침된 니 켈 입자와 달리, 용출된 금속이 페로브스카이트 표면에 소켓되어 메탄 개질 반응에서 불활성화를 유도하는 탄 화수소의 피독이 크게 감소된 용출 촉매를 제시하였다 (Fig. 14a). ${ }^{13)}$ 또한, 용출된 $\mathrm{Ni}$ 단일 메탈과 $\mathrm{Fe}-\mathrm{Ni}$ 바이 메탈 시스템을 비교하여 메탄 개질 반응의 촉매 안정성 을 조사하기 위해 $450{ }^{\circ} \mathrm{C}$ 에서 170 시간 동안의 연속 테 스트를 진행하였다(Fig.14b). ${ }^{33)} \mathrm{Ni}$ 촉매의 촉매 활성은 처음 120 시간에 걸쳐 열화되었지만, $\mathrm{Fe}-\mathrm{Ni} / \mathrm{p}$ 샘플의 촉매 활성은 처음 50 시간에 걸쳐 개선되었고, 나머지 a

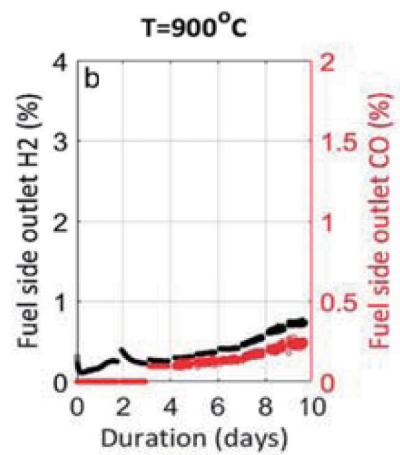

b

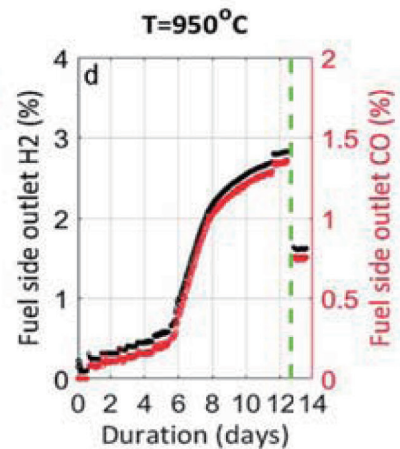

C

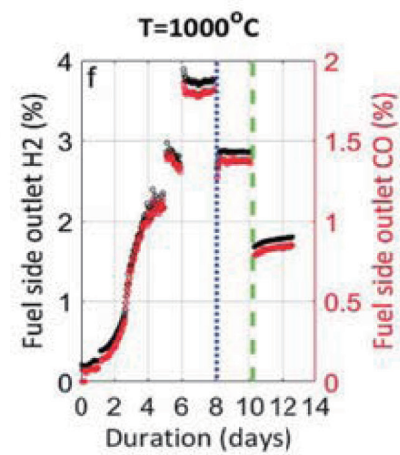

Fig. 16. a LCFN-1 $\left(900{ }^{\circ} \mathrm{C}\right)$, b LCFN-2 $\left(950^{\circ} \mathrm{C}\right)$ 및 $\mathrm{C} \mathrm{LCFN}-3\left(1000{ }^{\circ} \mathrm{C}\right)$ 촉매에 의해 $\mathrm{H}_{2}$ (black) 및 $\mathrm{CO}$ (red)의 생산 mole fraction. ${ }^{38)}$ 
a

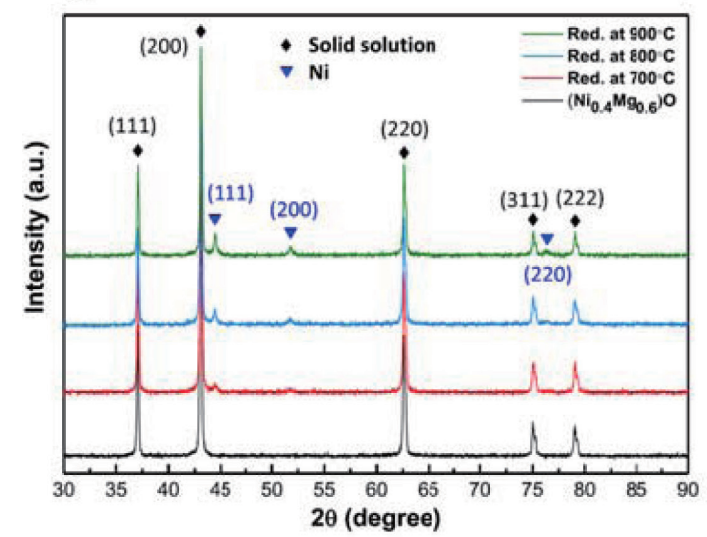

b
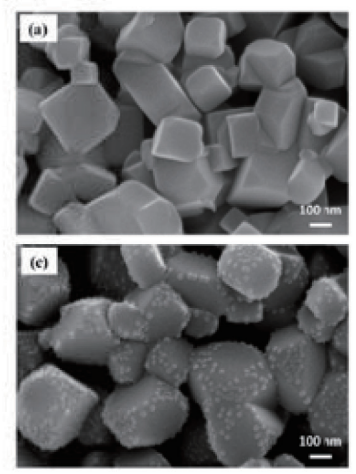
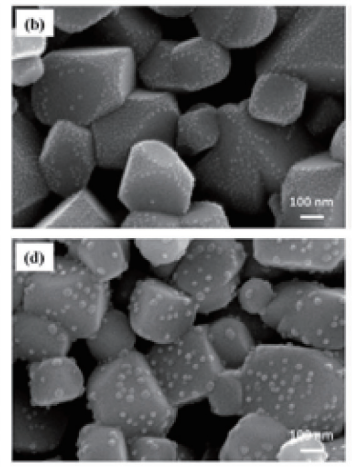

Fig. 17. a 700,800 및 $900{ }^{\circ} \mathrm{C}$ 에서 5 시간 동안 환원된 NiO-MgO의 XRD 결과. b (a) 초기 샘플, (b) $700{ }^{\circ} \mathrm{C}$, (c) $800{ }^{\circ} \mathrm{C}$, 및 (d) $900{ }^{\circ} \mathrm{C}$ 에서 5 시간 동안 환원된 촉매의 SEM 이미지 결과.99

측정 동안 유지되었다.

용출된 입자만 촉매 반응에 활용하려면, 산화 조건에 서 용출된 입자가 모체 페로브스카이트로 다시 이동하 는 것을 억제해야 한다. ${ }^{36)}$ 용출된 금속은 초기 위치에 고정된 채로 존재할 때 강한된 금속-지지체 산화물 결 합을 활용하여 기상 반응의 활성 및 안정성을 향상 시킬 수 있다. 이 때 모체 페로브스카이트 구조를 유지하기 위해 $\mathrm{A}$-사이트 결함을 두고 용출시키는 경우가 많이 보 고되고 있다.

초기 입자 배열을 유지할 수 있는 용출된 입자는 반응 온도 $\left(220{ }^{\circ} \mathrm{C}\right)$ 에서 650 시간 동안 촉매 활성이 유지됨을 보여주었다 (Fig. 15a), 또한, CoNi alloy는 코크에 의 한 피독 현상이 없는 것으로 확인되었다. $\mathrm{CO}$ 공급량 증 가에 따라, $\mathrm{Pt} / \mathrm{Al}_{2} \mathrm{O}_{3}$ 촉매에서의 활성 사이트인 $\mathrm{Pt}$ 에서 는 강한 $\mathrm{CO}$ 흡착력으로 인해 반응 속도가 느려진 반면, $\mathrm{CoNi}$ alloy의 $\mathrm{CO}_{2}$ 생산속도는 $\mathrm{CO}$ 몰분율 증가에 따라 향상되었다 (Fig. 15b). ${ }^{37)}$

Fig. 16. a c 는 LCFN-1, LCFN-2, LCFN-3을 $900{ }^{\circ} \mathrm{C}, 950{ }^{\circ} \mathrm{C}$ 및 $1000{ }^{\circ} \mathrm{C}$ 의 3 가지 다른 용출 온도에 서 합성한 촉매의 시간에 따른 $\mathrm{CH}_{4}$ 몰분율 변화를 보여 준다. $\mathrm{LCFN}-1$ 은 반응 활성 및 합성 가스의 생산률은 낮았지만, $\mathrm{LCFN}-2 . \mathrm{LCFN}-3$ 는 유사한 높은 활성을 보여주었다. LCFN-2. LCFN-3은 반응 도중에 온도를 $1000{ }^{\circ} \mathrm{C}$ 에서 $950{ }^{\circ} \mathrm{C}$ 로, $950{ }^{\circ} \mathrm{C}$ 에서 $900{ }^{\circ} \mathrm{C}$ 로 낮출 시,
반응 속도가 늦춰졌으나 안정성은 몇 일 동안 유지되었 다. 활성의 향상은 $\mathrm{Ni}^{0}$ 나노 입자의 형성 때문인 것이 여 러 분석을 통해 밝혀졌다. ${ }^{38)}$

\section{4. 폐로브스카이트 외 다른 산화물의 입자 용출 및 기상 반응에의 웅용}

금속의 용출 현상은 페로브스카이트계 물질에서 주로 보고되어 왔다. 그러나, 페로브스카이트 물질을 넘어서 기상 반응에 대한 촉매적인 이용이 입증된 물질에 이 현 상을 적용한다면, 다양한 산화물 촉매가 직면한 활성 개 선 및 안정성 문제를 동시에 효과적으로 해결할 수 있을 것이다. 앞서 설명된 금속의 용출 현상을 정밀하게 통제 한다면, 더 광범위한 산화물의 성능 개선 및 촉매의 재 사용을 용이하게 함에 따라 크게 경제적인 이득을 얻어 낼 수 있다. 이 파트에서는 다른 산화물들을 이용하여 용출 현상을 효과적으로 이용한 몇 가지 보고된 연구를 소개하여 용출 현상의 가능성을 확인한다.

금속은 초기에 산화물 지지체에 혼입되어 존재하며, 환 원 분위기에서 격자로부터 용출시켜 기상 반응에 적용하 였다. $\mathrm{NiO}-\mathrm{MgO}$ 를 이용한 methane steam reforming 반응에서, 초기에 제조된 분말에서 관찰된 모든 $\mathrm{XRD}$ 의 피크는 $\mathrm{Ni}_{\mathrm{x}} \mathrm{Mg}_{1-\mathrm{x}} \mathrm{O}$ 에 해당하였고, 니켈 산화물 $(\mathrm{NiO})$, 산 화 마그네슘 $(\mathrm{MgO})$, 또는 다른 2차상에 해당하는 피크 


\section{특 집 므황루이, 김형준, 한정우 ${ }^{\dagger}$}

a

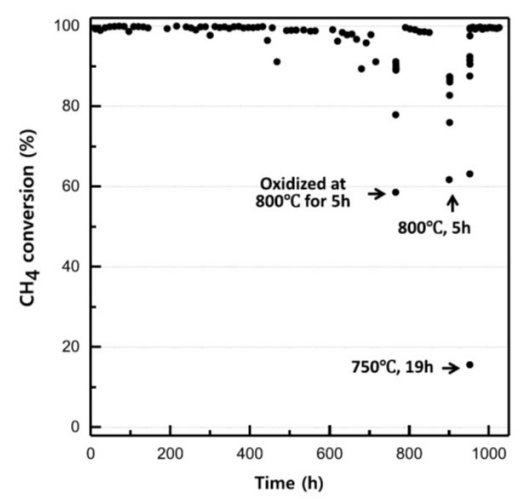

C

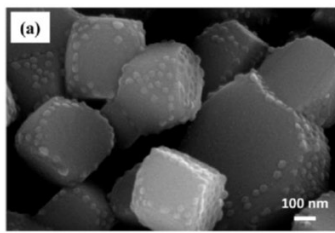

b
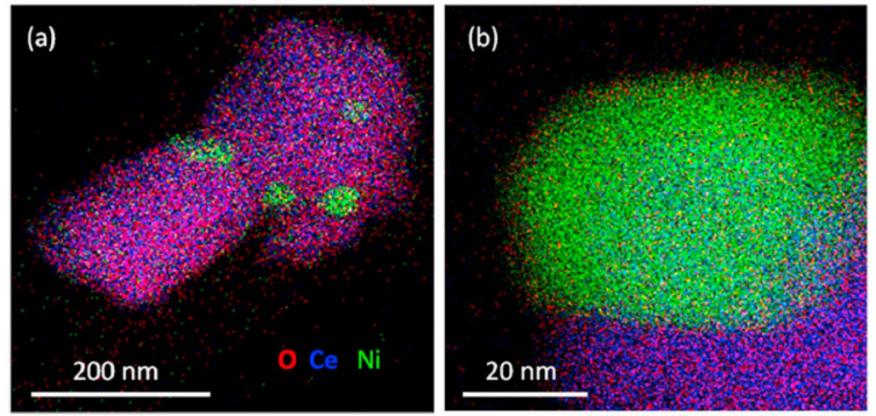
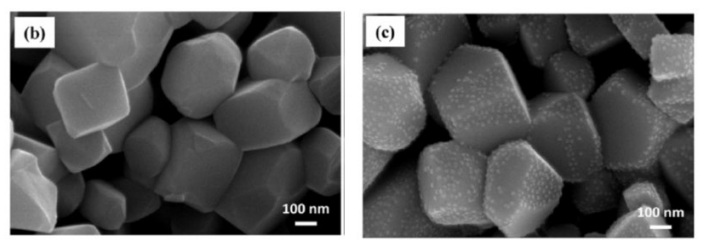

Fig. 18. a $750{ }^{\circ} \mathrm{C}$ 에서 1000 시간 동안 측정된 $\mathrm{CH}_{4}$ 전화율의 결과. ${ }^{39)} \mathrm{b} \mathrm{Ce}_{0.97} \mathrm{Ni}_{0.03} \mathrm{O}_{2-\delta}$ 로부터 용출된 $\mathrm{Ni} / \mathrm{CeO}_{2}$ 의 (a) 저배율 (b) 고배율의 SEM-EDS mapping 결과. ${ }^{40)} \mathrm{C}$ (a) 환원 처리, (b) 산화 처리, 및 (c) $800{ }^{\circ} \mathrm{C}$ 에서 5 시간 동안 재환원된 촉매의 SEM 이미지 결과. ${ }^{39)}$

는 관찰되지 않는 것으로 보고되었다 (Fig. 17a). ${ }^{39)}$ 이 결 과는 초기에 제조된 분말 촉매가 단일상 고용체 (solid solution)임을 나타내며, 환원 분위기에서 처리 후에 $\mathrm{NiO}-\mathrm{MgO}$ 은 단일상 고용체에서 용출된 금속성 $\mathrm{Ni}$ 이 나 노 크기로 표면에 형성된다 (Fig. 17a). 또한, 금속성 $\mathrm{Ni}$ 에 기인한 XRD peak의 intensity는 환원 온도가 상승함 에 따라 증가됨이 관찰되었다. 700,800 , 및 $900{ }^{\circ} \mathrm{C}$ 에서 환원된 샘플에 대한 평균 입자 크기는 18,25 , 및 $28 \mathrm{~nm}$ 로, 환원 온도가 상승함에 따라 용출된 $\mathrm{Ni}$ 금속 크기가 증가하였다 (Fig. 17a). ${ }^{39)}$ 이러한 결과는 SEM 이미지를 통해 더 쉽게 관찰되는데, 초기의 Fig. $17 \mathrm{~b}(\mathrm{a})$ 와 비교하여 온도가 상승함에 따라 촉매 표면의 금속성 $\mathrm{Ni}$ 을 명확하게 확인할 수 있었다 (Fig. 17b).

$\mathrm{Ni}$ 금속의 용출된 촉매는 장기 안정성 분석에서 1000 시간 동안 뚜렷한 활성 감소를 보이지 않았다 (Fig. 18a). ${ }^{32)}$ 일반적으로, methane steam reforming 반응에 서 촉매 표면에 탄소가 침적되어 촉매의 불활성화를 유도 하는 것으로 알려져 있다. ${ }^{41)}$ 그러나, 용출된 촉매에서는 탄소 침적에 대한 상당한 저항성을 보여주었을 뿐만 아
니라, $\mathrm{Ni}$ 와 촉매 표면 사이의 강한 anchoring 효과에 의 해 표면에 $\mathrm{Ni}$ 의 열적 안정성이 향상되었다 (Fig. 18a). 또 한, 동일한 샘플에 산화 및 환원 분위기에 변화를 주어 재 생 가능한 촉매 제조에 대한 가능성을 보고하였다. 촉매 를 $800{ }^{\circ} \mathrm{C}$ 에서 5 시간 동안 산화시키면, 금속성 $\mathrm{Ni}$ 은 촉 매 표면에서 완전히 사라졌지만, 다시 환원 처리를 해주 면 금속성 $\mathrm{Ni}$ 이 다시 표면에 형성되는 것을 볼 수 있다 (Fig. 18c). 반응 하에서 재생 가능한 촉매로써 이용가능 한지 명확히 확인하기 위해, Fig. 18a에서 반응 중에 촉 매에 산화 처리를 해주었다. 산화 분위기로 인해 용출된 $\mathrm{Ni}$ 은 단일상 지지 촉매로 이동하였고, 표면에 나노 크기 로 용출된 $\mathrm{Ni}$ 이 감소됨에 따라 전환율은 감소하였다. 흥 미롭게도, 다시 환원 분위기가 형성됨에 따라 빠르게 전 환율이 상승하였다 (Fig. 18a). 이러한 현상은 나노 입자 가 지지체에 가역적으로 이동할 수 있으며 촉매 표면에 불활성화를 유도할 수 있는 물질이 형성되어도 조건 변 화를 통해 촉매를 재생할 수 있음을 시사한다 (Fig. 18c). 또한, 나노 크기의 고용체는 methane dry reforming에 서도 효율적으로 적용되었는데, $\mathrm{NiO}-\mathrm{CeO}_{2}$ 에서 금속의 
a

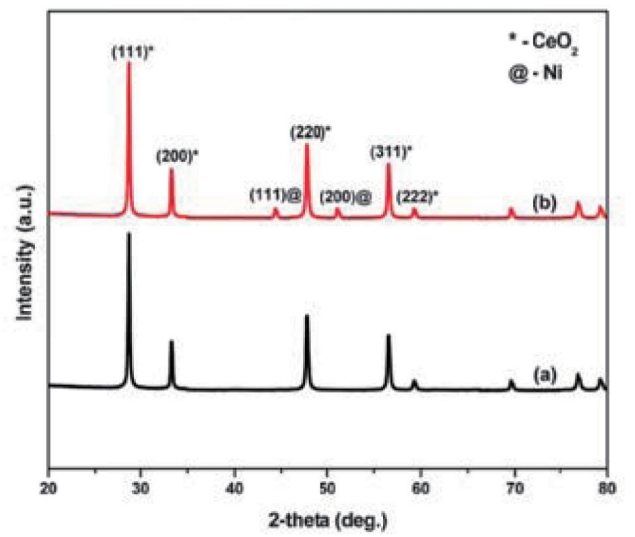

b

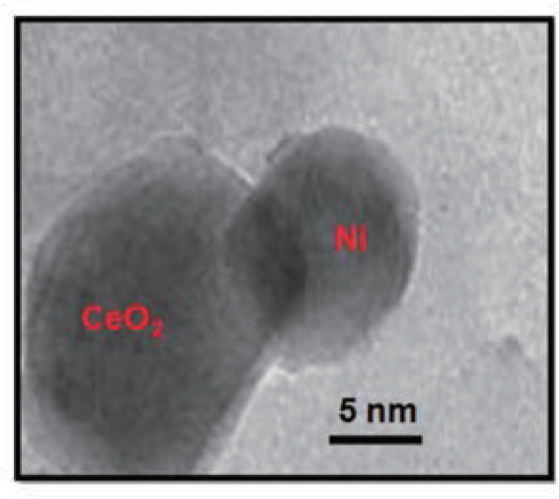

Fig. 19. a (a) 초기 합성된 촉매와 (b) NI가 용출된 촉매의 XRD 결과. b Ni가 용출된 촉매의 TEM 이미지 결과. ${ }^{45)}$

용출을 통해 형성된 촉매는 지지 촉매와의 강한 상호작용 으로 인한 높은 성능을 보였다(Fig. 18b). ${ }^{40)}$

$\mathrm{CeO}_{2}$ 촉매는 +4 에서 +3 로의 우수한 산화 환원 능력 으로 인해 산소 결함(oxygen defect) 형성의 용이성 및 높은 산소 저장 능력(oxygen storage capacity)이 입 증되었다. ${ }^{42)}$ 그러나 이러한 $\mathrm{CeO}_{2}$ 촉매의 우수한 특성에 도 불구하고, 저온에서는 귀금속 촉매와 같은 고활성 촉 매보다 현저히 낮은 촉매 활성을 갖는다. ${ }^{43)}$ 또한, 낮은 열적 안정성은 실용적인 촉매 개발에 한계점을 갖게 한 다. 많은 연구자들은 이러한 문제를 해결하기 위해서 활 성이 높은 다른 금속을 doping 또는 loading을 통해 성
능 개선을 시도하였지만, ${ }^{44)}$ 반응 과정 중 발생하는 촉매 의 입자 성장 및 표면에서 금속의 응집을 효과적으로 억 제하기에는 어려움이 있었다. 용출된 나노 입자는 향상 된 촉매 활성, 지지체와의 강한 anchoring으로 인해 안 정성 및 coking에 대한 저항성을 갖는다고 보고되었으 며, ${ }^{39)}$ 이러한 현상의 이용은 산화 반응에서 고성능 촉매 를 개발하기 위해 효과적으로 활용될 수 있다.

$\mathrm{CeO}_{2}$ 격자에 $\mathrm{Ni}$ doping으로 촉매 제조 후에, 환원 처 리하여 금속성 $\mathrm{Ni}$ 을 표면으로 성공적으로 용출시킬 수 있는 것으로 보고되었다. 이 문헌에서는 $\mathrm{Ni}^{2+}$ 가 벌크에 서 표면으로 확산된 후 $\mathrm{Ni}^{0}$ 을 형성하였으며, ${ }^{45)} \mathrm{CeO}_{2}$ 는
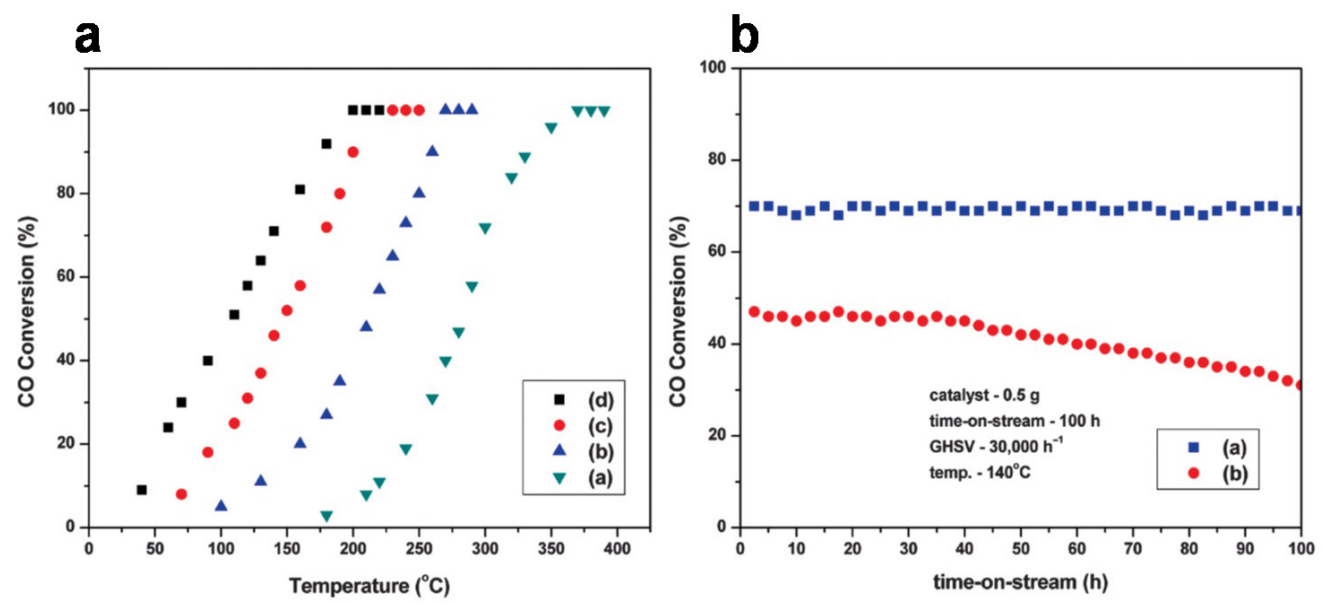

Fig. 20. a (a) $\mathrm{CeO}_{2}$ (b) $5 \% \mathrm{Ni}$, (c) $10 \% \mathrm{Ni}$ 가 포함된 초기에 제조된 촉매 및 (d) 초기에 $10 \% \mathrm{Ni}$ 가 혼입되어 용출된 촉매의 $\mathrm{CO}$ 산화 결과. $\mathrm{b}$ (a) Ni가 용출된 촉매 및 (b) 초기에 제조된 촉매의 100시간 동안 반응 하에서 수행된 안정성 테스트 결과. ${ }^{45)}$ 


\section{특 집}

환원 과정 중에 상변화가 발생하지 않았다 (Fig. 19a). 이는 $\mathrm{CeO}_{2}$ 촉매의 우수한 redox 안정성에 기인한 것 으로 볼 수 있다. 용출된 $\mathrm{Ni}$ 와 $\mathrm{CeO}_{2}$ 는 각각 $8.8 \mathrm{~nm}$ 와 $17.2 \mathrm{~nm}$ 의 크기로 관찰되었다 (Fig. 19a). 또한, TEM 이미지를 통해 용출된 $\mathrm{Ni}$ 을 추가 확인할 수 있었다 (Fig. 19b). 이렇게 용출된 촉매를 이용하여 CO 산화 반 응에 적용하였을 때, 초기에 doping된 촉매( $\mathrm{Ni}$ 가 용출 되기 전)의 전환율 $50 \%$ 에 해당하는 온도는 $150{ }^{\circ} \mathrm{C}$ 로 순수 $\mathrm{CeO}_{2}$ 보다 높은 촉매 활성을 보였다 (Fig. 19a). ${ }^{45)}$ 한편, $\mathrm{Ni}$ 이 용출된 촉매는 더욱 촉매 활성이 향상되어 $110{ }^{\circ} \mathrm{C}$ 에 서 전환율 $50 \%$ 를 달성하였다. 이는 일반적으로 제조된 촉매보다 더 높은 촉매 활성을 보여주며, 용출된 $\mathrm{Ni}$ 로 인한 활성 사이트의 더 많은 제공으로 인해 $\mathrm{CO}$ 활성화 에 중요한 역할을 하였다. ${ }^{45}$

용출된 촉매의 큰 장점은 표면에 형성된 나노 크기의 금속이 지지 촉매와 강한 결합을 하고 있기 때문에 금 속의 응집을 방지한다는 것이다. 반응 조건하에서 100 시간 동안 용출된 촉매의 반응을 수행한 결과, 측정 시 간 동안 활성 저하가 관찰되지 않았다 (Fig. 20a b). 반 면, 일반적으로 $\mathrm{Ni}$ 이 doping된 $\mathrm{CeO}_{2}$ 촉매는 40 시간부 터 활성 저하가 시작되어 100 시간 후에는 $16 \%$ 나 전환율 이 감소되었다 (Fig. 20b). 이러한 용출된 촉매는 $\mathrm{CO}$ 산 화 반응에서 요구되는 저온에서의 높은 활성을 나타낼 뿐만 아니라, 장기간 안정적이라는 것을 나타낸다. 또 한, 100 시간 반응 후에도 용출된 촉매의 비표면적은 유 의미한 변화가 관찰되지 않았다. ${ }^{45)}$ 결과적으로, 나노 크 기로 용출된 금속을 갖는 촉매는 증가된 반응 사이트로 인한 활성 개선과 지지 촉매와의 강한 결합으로 인해 촉 매의 불활성화를 억제할 수 있음을 시사한다.

\section{5. 요약 및 전망}

페로브스카이트 산화물에 기반한 용출 촉매는, 자동 차 배기가스 저감을 위해 TWC에 사용되는 촉매의 극한 고온 환원 산화 조건에 따른 응집으로 인한 불활성 문제 를 해결하고자 개발되었다. ${ }^{3,46-48)}$ 용출 촉매는 종래에 함침 또는 침전 방법으로 합성된 금속/지지체 촉매와 비
슷하면서도 본질적인 차이가 있어 보다 더 매력적인 장 점이 있다. 종래의 방법으로 합성된 촉매에는 금속과 지 지체 사이에 강한 결합을 형성시키는 것이 제한적이었 다. 이로 인해, 반응 조건(보통 고온 또는 고압)에 따라 금속 원자들은 응집되어 활성 사이트의 손실이 발생하 고, 활성 저하를 피할 수 없었다. 반응물과 강한 흡착 세 기를 갖는 금속들은 카본, 황 등 독성가스의 흡착도 선 호되기 때문에 피독을 피할 수 없다는 문제점이 있다. 재생을 시키려면 고온을 수반한 산화 분위기에서 활성 사이트 밖에 둘러 쌓이는 카본 또는 황을 태워 제거하는 과정을 추가적으로 진행해야 한다. 그러나, 이 과정에 서 금속 사이트의 손실이 때때로 발생하여 성능에 영향 을 미치게 된다. 반면, 용출 촉매에서 초기 합성 시 도핑 된 금속 원소는 벌크 격자 안에 고용체(solid solution) 형태로 존재하며, 환원 처리 후 도핑한 금속은 표면으 로 이동하여 최종적으로 지지 촉매와 강하게 anchoring 된다. 표면은 종래에 합성된 금속/지지체 촉매와 유사 하지만, 금속과 지지체 계면(interface)에 존재 형태가 다르기 때문에 촉매 특성은 다르게 관찰된다. 우수한 anchoring의 효과로 인해 고온에서의 금속의 이동을 방 지하여 응집 현상 방지할 수 있어 장기 안정성이 확보된 다. 더욱이, 환원 산화 조건에 따라 도핑된 금속의 지지 체 격자 및 표면 간의 이동으로 인해, 피독에 의해 유도 된 촉매의 불활성화를 효과적으로 방지할 수 있다. 이러 한 장점들을 이용하여 용출 촉매는 자동차 배기가스 저 감, 온실가스 화학 에너지로 전환 등과 같은 기상 반응 촉매의 발전에 현저하게 기여할 수 있다.

그러나 아직 해결해야 되는 과제들이 남아있다. 다양 한 금속 산화물에서 기상 반응에 효과적으로 적용하려 는 용출 현상의 구동력(driving force)에 대한 연구는 실 험 및 이론적으로 다양하게 진행되고 있으나, 보편성 있 는 이론의 제기가 필요하다. 또한, 용출된 입자의 화학 조성, 크기, 형태(morphology)등은 용출 조건에 따라 최적화되어야 촉매 활성을 향상시키는데 큰 이점을 취 할 수 있다. 페로브스카이트 산화물을 지지체로 사용할 경우, 산화물 자체의 입자가 크고 작은 비표면적을 갖기 때문에 촉매 활성을 향상시키는데 한계가 있다. 그러므 
로 본문에서 언급하였듯이 비페로브스카이트 계 산화물 지지체(입자 크기가 작고, 높은 환원성을 갖는 지지체) 에 용출 현상을 적용시키는 방안이 제시되고 있다. 용출 현상이 성공적으로 기상 반응에 응용된 연구들은 넓은 응용 분야에서 계속 보고되고 있다. 페로브스카이트와 비페로브스카이트 모두에서도 환원 분위기를 통해 용출 현상이 발생하며, 이러한 현상에서만 발현되는 특성을 이용하여 고성능 촉매를 개발하려는 시도가 있었다. 점 점 확장되고 있는 물질들과 현상에 대한 깊은 이해를 통 해 이러한 용출 현상은 앞으로 고성능 촉매를 개발함에 있어서 합리적인 접근법으로 유용하게 이용될 것이다.

\section{감사의 글}

이 논문은 정부(과학기술정보통신부)의 재원으로 한 국연구재단의 지원을 받아 수행된 연구임 (NRF-2016 R1A5A1009592, NRF-2018R1A2B2002875).

\section{REFERENCES}

1. Lindenthal, L.; Rameshan, R.; Summerer, H.; Ruh, T.; Popovic, J.; Nenning, A.; Löffler, S.; Opitz, A. K.; Blaha, P.; Rameshan, C. «Modifying the Surface Structure of Perovskite-Based Catalysts by Nanoparticle Exsolution.》Catalysts, 10 [3] 1-14 (2020).

2. Tanaka, H.; Misono, M. "Advances in Designing Perovskite Catalysts." Curr Opin Solid St M 5 [5] 381-387 (2001).

3. Nishihata, Y.; J.Mizuki; T.Akao; H.Tanaka; M.Uenishi; M.Kimura; T.Okamoto; N.Hamada "Self-Regeneration of A Pd-Perovskite Catalyst for Automotive Emissions Control." Nature, 418 [6894] 164-167 (2002).

4. Kim, J. H.; Park, Y. M.; Kim, T.; Kim, H. "Characterizations of Composite Cathodes With $\mathrm{La}_{0.6} \mathrm{Sr}_{0.4} \mathrm{Co}_{0.2} \mathrm{Fe}_{0.8} \mathrm{O}_{3-\delta}$ and $\mathrm{Ce}_{0.9} \mathrm{Gd}_{0.1} \mathrm{O}_{1.95}$ for Solid Oxide Fuel Cells." Korean J. Chem. Eng., 29 [3] 349-355 (2011).

5. Kwon, O.; Kim, K.; Joo, S.; Jeong, H. Y.; Shin, J.; Han, J. W.; Sengodan, S.; Kim, G. "Self-assembled Alloy Nanoparticles in A
Layered Double Perovskite as A Fuel Oxidation Catalyst for Solid Oxide Fuel Cells." J. Mater. Chem. A, 6 [33] 15947-15953 (2018).

6. Jo, Y. R.; Koo, B.; Seo, M. J.; Kim, J. K.; Lee, S.; Kim, K.; Han, J. W.; Jung, W.; Kim, B. J. "Growth Kinetics of Individual Co Particles Ex-Solved on $\mathrm{SrTi}_{0.75} \mathrm{Co}_{0.25} \mathrm{O}_{3}$-delta Polycrystalline Perovskite Thin Films." J. Am. Chem. Soc., 141 [16] 6690-6697 (2019).

7. Joo, S.; Kwon, O.; Kim, K.; Kim, S.; Kim, H.; Shin, J.; Jeong, H. Y.; Sengodan, S.; Han, J. W.; Kim, G. "Cation-Swapped Homogeneous Nanoparticles in Perovskite Oxides for High Power Density." Nat. Commun., 10 [1] 697 (2019).

8. Choi, M.; Ibrahim, I. A. M.; Kim, K.; Koo, J. Y.; Kim, S. J.; Son, J. W.; Han, J. W.; Lee, W. "Engineering of Charged Defects at Perovskite Oxide Surfaces for Exceptionally Stable Solid Oxide Fuel Cell Electrodes." ACS Appl. Mater. Interfaces, 12 [19] 21494-21504 (2020).

9. Jacobs, R.; Mayeshiba, T.; Booske, J.; Morgan, D. "Material Discovery and Design Principles For Stable, High Activity Perovskite Cathodes for Solid Oxide Fuel Cells.” Adv. Energy Mater., 8 [11] (2018).

10. Kwon, O.; Sengodan, S.; Kim, K.; Kim, G.; Jeong, H. Y.; Shin, J.; Ju, Y. W.; Han, J. W.; Kim, G. "Exsolution Trends and Co-Segregation Aspects of Self-Grown Catalyst Nanoparticles in Perovskites." Nat. Commun., 815967 (2017).

11. Koo, B.; Kim, K.; Kim, J. K.; Kwon, H.; Han, J. W.; Jung, W. "Sr Segregation in Perovskite Oxides: Why It Happens and How It Exists.” Joule, 2 [8] 1476-1499 (2018).

12. Kim, K.; Lim, C.; Han, J. W. "Computational Approaches to The Exsolution Phenomena in Perovskite Oxides with A View To Design Highly Durable and Active Anodes for Solid Oxide Fuel Cells." Korean J. Chem. Eng., in press (2020).

13. Neagu, D.; Oh, T. S.; Miller, D. N.; Menard, H.; Bukhari, S. M.; Gamble, S. R.; Gorte, R. J.; Vohs, J. M.; Irvine, J. T. S. "NanoSocketed Nickel Particles with Enhanced Coking Resistance Grown In Situ by Redox 
Exsolution.” Nat. Commun., 68120 (2015).

14. Li, S.; Qin, Q.; Xie, K.; Wang, Y.; Wu, Y. "High-Performance Fuel Electrodes Based on $\mathrm{NbTi}_{0.5} \mathrm{M}_{0.5} \mathrm{O}_{4}(\mathrm{M}=\mathrm{Ni}, \mathrm{Cu})$ with Reversible Exsolution of The Nano-Catalyst for Steam Electrolysis.” J. Mater. Chem. A, 1 [31] (2013).

15. Pilger, F.; Testino, A.; Carino, A.; Proff, C.; Kambolis, A.; Cervellino, A.; Ludwig, C. "Size Control of Pt Clusters on $\mathrm{CeO}_{2}$ Nanoparticles via An Incorporation - Segregation Mechanism and Study of Segregation Kinetics." ACS Catal., 6 [6] 3688-3699 (2016).

16. Kurnatowska, M.; Kepinski, L.; Mista, W. "Structure Evolution of Nanocrystalline $\mathrm{Ce}_{1-\mathrm{x}} \mathrm{Pd}_{\mathrm{x}} \mathrm{O}_{2-\mathrm{y}}$ Mixed Oxide In Oxidizing And Reducing Atmosphere: Reduction-Induced Activity in Low-Temperature CO Oxidation." Appl. Catal., B : Environmental 117-118 135-147 (2012).

17. Kurnatowska, M.; Schuster, M. E.; Mista, W.; Kepinski, L. "Self-Regenerative Property of Nanocrystalline $\mathrm{Ce}_{0.89} \mathrm{M}_{0,11} \mathrm{O}_{2-\mathrm{y}}(\mathrm{M}=\mathrm{Pd}, \mathrm{Rh})$ Mixed Oxides." ChemCatChem, 6 [11] 31253131 (2014).

18. Gan, L.; Ye, L.; Ruan, C.; Chen, S.; Xie, K. "Redox-Reversible Iron Orthovanadate Cathode for Solid Oxide Steam Electrolyzer." Adv. Sci., (Weinh) 3 [2] 1500186 (2016).

19. Papargyriou, D.; Miller, D. N.; Sirr Irvine, J. T. "Exsolution of $\mathrm{Fe}-\mathrm{Ni}$ Alloy Nanoparticles from ( $\mathrm{La}, \mathrm{Sr})(\mathrm{Cr}, \mathrm{Fe}, \mathrm{Ni}) \mathrm{O}_{3}$ Perovskites as Potential Oxygen Transport Membrane Catalysts for Methane Reforming." J. Mater. Chem. A, 7 [26] 15812-15822 (2019).

20. Lai, K.-Y.; Manthiram, A. "Evolution of Exsolved Nanoparticles on A Perovskite Oxide Surface during A Redox Process." Chem. Mater., 30 [8] 2838-2847 (2018).

21. Katz, M. B.; Graham, G. W.; Duan, Y.; Liu, H.; Adamo, C.; Schlom, D. G.; Pan, X. "SelfRegeneration of $\mathrm{Pd}-\mathrm{LaFeO}_{3}$ Catalysts: New Insight from Atomic-Resolution Electron Microscopy.” J. Am. Chem. Soc., 133 [45] 18090-3 (2011).

22. Steiger, P.; Nachtegaal, M.; Kröcher, O.; Ferri, D. «Reversible Segregation of $\mathrm{Ni}$ in $\mathrm{LaFe}_{0.8} \mathrm{Ni}_{0.2} \mathrm{O}_{3 \pm \delta}$ during Coke Removal.》 ChemCatChem, 10 [19] 4456-4464 (2018).

23. Steiger, P.; Delmelle, R.; Foppiano, D.; Holzer, L.; Heel, A.; Nachtegaal, M.; Krocher, O.; Ferri, D. "Structural Reversibility and Nickel Particle Stability in Lanthanum Iron Nickel Perovskite-Type Catalysts." ChemSusChem, 10 [11] 2505-2517 (2017).

24. Sun, Y. F.; Li, J. H.; Cui, L.; Hua, B.; Cui, S. H.; Li, J.; Luo, J. L. "Correction: A-site-deficiency Facilitated In Situ Growth of Bimetallic Ni-Fe Nano-Alloys: A Novel Coking-Tolerant Fuel Cell Anode Catalyst." Nanoscale, 9 [2] 947 (2017).

25. Zhu, X.; Li, K.; Neal, L.; Li, F. "Perovskites as Geo-Inspired Oxygen Storage Materials for Chemical Looping and Three-Way Catalysis: A Perspective.” ACS Catal., 8 [9] 8213-8236 (2018).

26. Uenishi, M.; Tanaka, H.; Taniguchi, M.; Tan, I.; Nishihata, Y.; Mizuki, J. i.; Kobayashi, T. "Time Evolution of Palladium Structure Change with Redox Fluctuations in a $\mathrm{LaFePdO}_{3}$ Perovskite Automotive Catalyst by High-Speed Analysis with In Situ DXAFS." Catal. Commun., 9 [2] 311-314 (2008).

27. Keav, S.; Matam, S.; Ferri, D.; Weidenkaff, A. "Structured Perovskite-Based Catalysts and Their Application as Three-Way Catalytic Converters-A Review." Catalysts, 4 [3] 226255 (2014).

28. Uenishi, M.; Taniguchi, M.; Tanaka, H.; Kimura, M.; Nishihata, Y.; Mizuki, J.; Kobayashi, T. "Redox Behavior of Palladium at Start-Up in the Perovskite-Type $\mathrm{LaFePdO}_{\mathrm{x}}$ Automotive Catalysts Showing A SelfRegenerative Function." Appl. Catal., B : Environmental 57 [4] 267-273 (2005).

29. Tanaka, H.; Taniguchi, M.; Uenishi, M.; Kajita, N.; Tan, I.; Nishihata, Y.; Mizuki, J.; Narita, K.; Kimura, M.; Kaneko, K. "SelfRegenerating Rh- and Pt-Based Perovskite Catalysts for Automotive-Emissions Control." Angew. Chem., Int. Ed. Engl., 45 [36] 59986002 (2006).

30. Taniguchi, M.; Tanaka, H.; Uenishi, M.; Tan, I.; Nishihata, Y.; Mizuki, J. i.; Suzuki, H.; 
Narita, K. Hirai, A.; Kimura, M. "The SelfRegenerative $\mathrm{Pd}-, \mathrm{Rh}-$, and $\mathrm{Pt}-$ Perovskite Catalysts." Top. Catal., 42-43 [1-4] 367-371 (2007).

31. Steiger, P.; Kröcher, O.; Ferri, D. «Increased Nickel Exsolution from LaFe ${ }_{0.8} \mathrm{Ni}_{0.2} \mathrm{O}_{3}$ Perovskite-Derived $\mathrm{CO}_{2}$ Methanation Catalysts Through Strontium Doping." Appl. Catal., A : General 590 (2020).

32. Tada, S.; Ono, T.; Kikuchi, R. "Regeneration Behavior of Reforming Catalysts Based on Perovskite Oxides $\mathrm{LaM}_{0.95} \mathrm{Rh}_{0.05} \mathrm{O}_{3}$ (M: Cr, Co, $\mathrm{Fe}$ ) by Redox Treatment." Fuel, 269 (2020).

33. Papaioannou, E. I.; Neagu, D.; Ramli, W. K. W.; Irvine, J. T. S.; Metcalfe, I. S. "SulfurTolerant, Exsolved $\mathrm{Fe}$ - Ni Alloy Nanoparticles For CO Oxidation.” Top. Catal., 62 [17-20] 1149-1156 (2018).

34. Malamis, S. A.; Harrington, R. J.; Katz, M. B.; Koerschner, D. S.; Zhang, S.; Cheng, Y.; Xu, L.; Jen, H.-W.; McCabe, R. W.; Graham, G. W.; Pan, X. "Comparison of Precious Metal Doped and Impregnated Perovskite Oxides For TWC Application." Catal. Today, 258 535-542 (2015).

35. Tang, C.; Kousi, K.; Neagu, D.; Portoles, J.; Papaioannou, E. I.; Metcalfe, I. S. "Towards Efficient Use of Noble Metals via Exsolution Exemplified for CO Oxidation." Nanoscale, 11 [36] 16935-16944 (2019).

36. Neagu, D.; Tsekouras, G.; Miller, D. N.; Menard, H.; Irvine, J. T. "In Situ Growth of Nanoparticles through Control of Non-Stoichiometry." Nat. Chem., 5 [11] 916-23 (2013).

37. Neagu, D.; Papaioannou, E. I.; Ramli, W. K. W.; Miller, D. N.; Murdoch, B. J.; Menard, H.; Umar, A.; Barlow, A. J.; Cumpson, P. J.; Irvine, J. T. S.; Metcalfe, I. S. "Demonstration of Chemistry at A Point through Restructuring and Catalytic Activation at Anchored Nanoparticles." Nat. Commun., 8 [1] 1855 (2017).

38. Dimitrakopoulos, G.; Ghoniem, A. F.; Yildiz, B. "In Situ Catalyst Exsolution on Perovskite Oxides for The Production of $\mathrm{CO}$ and Synthesis Gas In Ceramic Membrane Reactors." Sustainable
Energy Fuels, 3 [9] 2347-2355 (2019).

39. Park, Y. S.; Kang, M.; Byeon, P.; Chung, S.-Y.; Nakayama, T.; Ko, T.; Hwang, H. "Fabrication of A Regenerable Ni Supported $\mathrm{NiO}-\mathrm{MgO}$ Catalyst for Methane Steam Reforming by Exsolution." J. Power Sources, 397 318-324 (2018).

40. Padi, S. P.; Shelly, L.; Komarala, E. P.; Schweke, D.; Hayun, S.; Rosen, B. A. "Coke-Free Methane Dry Reforming Over Nano-Sized $\mathrm{NiO}-\mathrm{CeO}_{2}$ Solid Solution after Exsolution." Catal. Commun., 138 (2020).

41. Roh, H. "Methane-Reforming Reactions over $\mathrm{Ni} / \mathrm{Ce}-\mathrm{ZrO}_{2} / \theta-\mathrm{Al}_{2} \mathrm{O}_{3}$ Catalysts." Appl. Catal., A: General 251 [2] 275-283 (2003).

42. Reddy, B. M.; Bharali, P.; Saikia, P. "Structural Characterization and Catalytic Activity of Nanosized $\mathrm{Ce}_{\mathrm{x}} \mathrm{M}_{1-\mathrm{x}} \mathrm{O}_{2}(\mathrm{M}=\mathrm{Zr}$ and Hf) Mixed Oxides.” J. Phys. Chem. C, 112 11729-11737 (2008).

43. Kim, H. J.; Jang, M. G.; Shin, D.; Han, J. W. "Design of Ceria Catalysts for LowTemperature CO Oxidation." ChemCatChem, 12 [1] 11-26 (2019).

44. Campisciano, V.; Gruttadauria, M.; Giacalone, F. "Modified Nanocarbons for Catalysis." ChemCatChem, 11 [1] 90-133 (2018).

45. Singhania, A.; Gupta, S. M. "Nickel Nanocatalyst Ex-Solution from Ceria-Nickel Oxide Solid Solution for Low Temperature CO Oxidation.” J. Nanosci. Nanotechnol., 18 [7] 4614-4620 (2018).

46. Tanaka, H.; Fujikawa, H.; Takahashi, 1. "Perovskite-Pd Three-Way Catalysts for Automotive Applications." SAE Tech. Pap., 930251 63-76 (1993).

47. H.Tanaka; H.Fujikawa; I.Takahashi "Excellent Oxygen Storage Capacity of PerovskitePd Three-Way-Catalysts." SAE Tech. Pap., 950256 289-301 (1995).

48. Tanaka, H.; Uenishi, M.; tan, I. "An Intelligent Catalyst." SAE Tech. Pap., 01 [1301] (2001). 


\section{특 집}

\section{ㅇ한ㄴ 정 우}

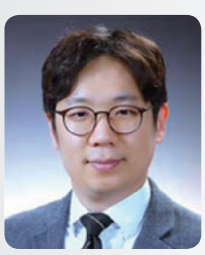

- 1998-2005 서울대학교 화학생물공학부 학사

ㅇ 2006-2007 Carnegie Mellon University 화학공학과 석사

- 2008-2010 Georgia Institute of Technology 화학생명공학부 박사

- 2010-2012 MIT 원자핵공학과 박사후연구원

• 2012-2018 서울시립대학교 화학공학과 조/부교수

( 2018-현 재 포항공과대학교 화학공학과 부교수

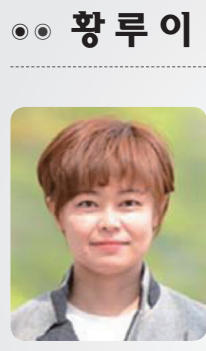

- 2004-2009 중국 정주경공업대학교 화학공학과 학사

( 2009-2011 서울시립대학교 화학공학과 석사

- 2011-2014 이일산업(주) 엔지니어

• 2014-2016 차스텍이앤씨(주) 공정 안전 엔지니어

(0) 2018-현 재 포항공과대학교 화학공학과 박사과정

\section{ㅇ․ 김형 준}

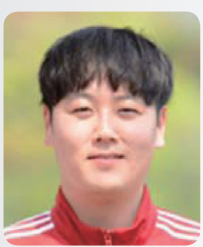

( 2010-2017 호서대학교 화학공학과 학사

( 2017-2019 서울시립대학교 화학공학과 석사

( 2019-현 재 포항공과대학교 화학공학과 박사과정 